Keywords: Tank Farm, Tank

Closure, Tank 5F

Retention: Permanent

\title{
Analysis of the Tank 5F Final Characterization Samples-2011 (U)
}

\author{
L. N. Oji, D. Diprete, C. J. Coleman \\ and M. S. Hay
}

August, 2012

Savannah River National Laboratory

Savannah River Nuclear Solutions

Aiken, SC 29808

Prepared for the U.S. Department of Energy under contract number DE-AC09-08SR22470.

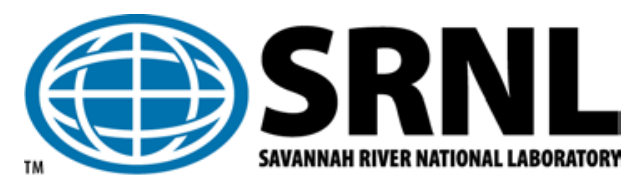




\section{DISCLAIMER}

This work was prepared under an agreement with and funded by the U.S. Government. Neither the U.S. Government or its employees, nor any of its contractors, subcontractors or their employees, makes any express or implied:

1. warranty or assumes any legal liability for the accuracy, completeness, or for the use or results of such use of any information, product, or process disclosed; or

2. representation that such use or results of such use would not infringe privately owned rights; or

3. endorsement or recommendation of any specifically identified commercial product, process, or service.

Any views and opinions of authors expressed in this work do not necessarily state or reflect those of the United States Government, or its contractors, or subcontractors.

Printed in the United States of America

Prepared for

U.S. Department of Energy 
SRNL-STI-2012-00034, Rev. 1 August 3, 2012

\section{REVIEWS AND APPROVALS}

Page 3 of 50

\section{AUTHORS:}

L. N. Oji, Author, Advanced Characterization \& Processing

Date

D. Diprete, Co-author, SRNL Analytical Development

Date

C. J. Coleman, Co-author, SRNL Analytical Development

Date

M. S. Hay, Co-author, Advanced Characterization \& Processing

Date

\section{TECHNICAL REVIEW:}

S. H. Reboul, Process Technology Programs

Date

\section{APPROVALS:}

F. M. Pennebaker, Manager, Advanced Characterization \& Processing

Date

S. L. Marra, Manager,

Date

Environmental \& Chemical Process Technology Research Programs

P. E. Carroll, SRR Engineering

Date

M. J. Mahoney, Closure \& Waste Disposal Authority

Date

A. J. Tisler, Manager, SRR Engineering

Date 


\begin{tabular}{|c|c|c|}
\hline \multicolumn{3}{|c|}{ LIST OF REVISIONS } \\
\hline $\begin{array}{l}\text { Revision } \\
\text { Number }\end{array}$ & Summary of Changes & Date \\
\hline 1.0 & $\begin{array}{l}\text { Updated the ICPES elemental values reported for Tank 5F } \\
\text { composite sample number 3, run 2, in Table } 7 \text { page } 23 \text {. } \\
\text { Revision of the report was necessary to correct for elemental } \\
\text { metal concentration transcription error affecting original data. }\end{array}$ & 8/03/12 \\
\hline 1.0 & $\begin{array}{l}\text { Added AD sample tracking numbers (LIMS \#) on pages } 33 \\
\text { and } 34 \text { as appendix A-0 and cited appendix A-0 in the result } \\
\text { section of the report in paragraph } 1 .\end{array}$ & 8/03/12 \\
\hline 1.0 & $\begin{array}{l}\text { Re-oriented Figure } 2 \text { and modified it to change the sampling } \\
\text { notation on the southeast corner consistent with the revision to } \\
\text { the TTR. }\end{array}$ & 8/03/12 \\
\hline 1.0 & Typo in appendix B was corrected. & 8/03/12 \\
\hline 1.0 & $\begin{array}{l}\text { Document formatting was performed in different sections of } \\
\text { the report. }\end{array}$ & 8/03/12 \\
\hline 1.0 & $\begin{array}{l}\text { Updated references to the following document recent versions: } \\
\text { (1) Technical Task Request number HLE-TTR-2010-004, Rev } \\
\text { 7. (2) Task Technical and Quality Assurance Plan for the } \\
\text { Analysis of the Tank 5F and Tank 6F Final Characterization } \\
\text { Samples-SRNL-RP-2010-01695, Rev. } 1 \text { and (3) Tank } 5 \\
\text { Sampling and Analysis Plan-SRR-LWE-2010-00285, Rev. 1, } \\
\text { Nov. 15, 2010. }\end{array}$ & 8/03/12 \\
\hline
\end{tabular}




\section{EXECUTIVE SUMMARY}

The Savannah River National Laboratory (SRNL) was requested by SRR to provide sample preparation and analysis of the Tank $5 \mathrm{~F}$ final characterization samples to determine the residual tank inventory prior to grouting. Two types of samples were collected and delivered to SRNL: floor samples across the tank and subsurface samples from mounds near risers 1 and 5 of Tank 5F. These samples were taken from Tank 5F between January and March 2011. These samples from individual locations in the tank (nine floor samples and six mound Tank 5F samples) were each homogenized and combined in a given proportion into 3 distinct composite samples to mimic the average composition in the entire tank. These Tank 5F composite samples were analyzed for radiological, chemical and elemental components. Additional measurements performed on the Tank 5F composite samples include bulk density and water leaching of the solids to account for water soluble species. With analyses for certain challenging radionuclides as the exception, all composite Tank 5F samples were analyzed and reported in triplicate.

The target detection limits for isotopes analyzed were based on customer desired detection limits as specified in the technical task request documents. SRNL developed new methodologies to meet these target detection limits and provide data for the extensive suite of components. While many of the target detection limits were met for the species characterized for Tank 5F, as specified in the technical task request, some were not met. In a few cases, the relatively high levels of radioactive species of the same element or a chemically similar element precluded the ability to measure some isotopes to low levels. The Technical Task Request allows that while the analyses of these isotopes is needed, meeting the detection limits for these isotopes is a lower priority than meeting detection limits for the other specified isotopes. The isotopes whose detection limits were not met in all cases included the following: Al-26, Sn-126, Sb-126, Sb-126m, Eu-152 and Cf-249. SRNL, in conjunction with the plant customer, reviewed all these cases and determined that the impacts were negligible. 


\section{TABLE OF CONTENTS}

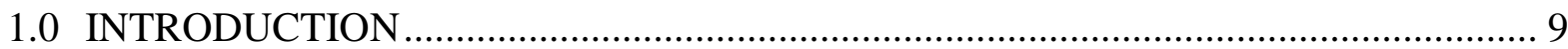

2.0 SAMPLING AND SAMPLE PREPARATION FOR CHARACTERIZATION ........... 11

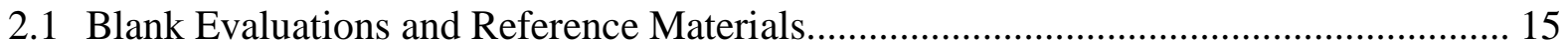

2.2 Leaching Characterization of Tank 5F Solids ............................................................ 15

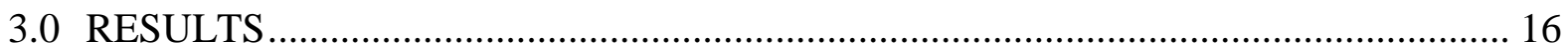

3.1 Data Quality and Presentations for Routine Radionuclide Constituents....................... 17

3.2 Data Quality and Presentations for Elemental Constituents ...................................... 18

3.3 Data Quality and Presentations for Non-Routine Radionuclide Analytes. .................... 19

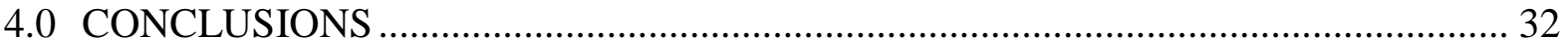

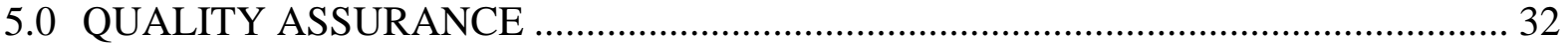

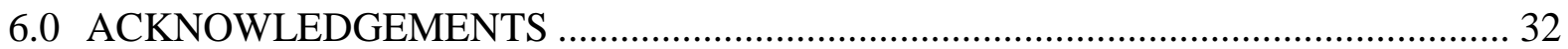

Appendix A-0: AD Tank 5F Characterization Tracking Numbers..................................... 33

Appendix A-1: Chemical Composition of Reference Tank 8 Simulant ............................... 35

Appendix A-2: Chemical Composition of Analyzed Reference Glass................................ 36

Appendix A-3: Analytical Results for Challenging Radiological Constituents .................... 39

Appendix A-4: “As-received” and Composited Sample Bulk Densities, g/mL ................... 41

Appendix A-5: Tank 5F Homogenized Discrete Sample, Composited Sample Bulk Densities

$(\mathrm{g} / \mathrm{mL})$ and Composited Sample weight percent solids ........................................... 42

Appendix A-6: Tank 5F discrete and composite samples in stock................................... 43

Appendix B: Summary of Analytical Methods .......................................................... 44 


\section{LIST OF TABLES}

Table 1. Composite Samples Volumetric Distribution .................................................. 12

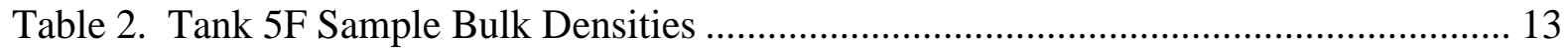

Table 3. Tank 5F sample compositions for Composite samples 1, 2 and 3........................ 14

Table 4. Weight Percent Solids for Tank 5F Composite Samples..................................... 14

Table 5. Elemental Constituents in Tank 5F Composite Sample \# 1, mg/g sample............. 21

Table 6. Elemental Constituents in Tank 5F Composite Sample \# 2, mg/g sample............. 22

Table 7. Elemental Constituents in Tank 5F- Composite Sample \# 3, mg/g sample ............ 23

Table 8. Anions Leached per gram of Tank 5F- Composite Sample \# 1............................. 24

Table 9. Anions Leached per gram of Tank 5F- Composite Sample \# 2 ............................. 24

Table 10. Anions Leached per gram of Tank 5F- Composite Sample \# 3........................... 24

Table 11. Radiological Constituents for Tank 5F Composite Sample \#1, $\mu \mathrm{Ci} / \mathrm{g}$. ................ 25

Table 12. Radiological Constituents for Tank 5F Composite Sample \#2, $\mu \mathrm{Ci} / \mathrm{g}$. ................ 27

Table 13. Radiological Constituents for Tank 5F Composite Sample \#3, $\mu \mathrm{Ci} / \mathrm{g}$................. 29

Table 14. Tank 5F Composite Sample \#1: Challenging Radiological Constituents, $\mu \mathrm{Ci} / \mathrm{g}$. . 31

Table 15. Tank 5F Composite Sample \#2: Challenging Radiological Constituents, $\mu \mathrm{Ci} / \mathrm{g}$. . 31

Table 16. Tank 5F Composite Sample \#3: Challenging Radiological Constituents, $\mu \mathrm{Ci} / \mathrm{g}$. . 31

\section{LIST OF FIGURES}

Figure 1. Photo images of “as-received” Tank 5F samples............................................ 10

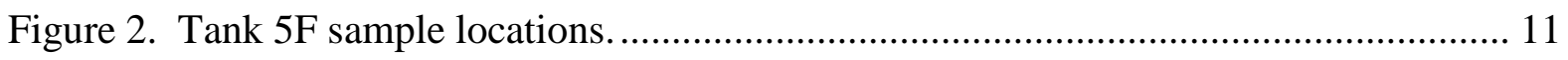




\section{LIST OF ABBREVIATIONS}

$\begin{array}{ll}\text { AD } & \text { Analytical Development } \\ \text { ARG } & \text { Analyzed Reference Glass } \\ \text { AQR } & \text { Aqua Regia Digestions } \\ \text { DL } & \text { Detection limit: As used in mass spectrophotometer analyses or ICP- } \\ & \text { ES; three times the standard deviation of the blank measurements. } \\ \text { ICP-ES } & \text { Inductively Coupled Plasma-Atomic Emission Spectroscopy } \\ \text { ICP-MS } & \text { Inductively Coupled Plasma-Mass Spectroscopy } \\ \text { LWO } & \text { Liquid Waste Operations } \\ \text { MDA } & \text { Minimum Detectable Activity: Minimum detectable activity is the } \\ & \text { value above which instrument signal can be considered real. } \\ \text { PF } & \text { Sodium Peroxide/Hydroxide Fusions } \\ \text { PMP } & \text { Polymethyl Pentane } \\ \text { PuTTA } & \text { Plutonium thenoyltrifluoro-acetone } \\ \text { UL } & \text { Upper limit: Activity observed but biased high due to spectral } \\ & \text { interference or blank contamination. } \\ \text { SRNL } & \text { Savannah River National Laboratory } \\ \text { SRR } & \text { Savannah River Remediation } \\ \text { TTQAP } & \text { Task Technical and Quality Assurance Plan } \\ \text { TTR } & \text { Technical Task Request }\end{array}$




\subsection{INTRODUCTION}

Savannah River Remediation (SRR) is preparing Tank 5F for closure. The Savannah River National Laboratory (SRNL) was requested by SRR to provide sample preparation and analysis of the Tank $5 \mathrm{~F}$ final characterization samples to determine the residual tank inventory prior to grouting. In all, nine floor samples and six mound Tank 5F samples were provided by SRR. A photo image of some of the "as-received" Tank 5F samples is shown in Figure 1 (three mound samples and six floor samples). These Tank 5F samples were taken between January and March 2011 and made available to SRNL.

The types of Tank 5F samples collected and delivered to SRNL for analysis were floor samples across the tank and subsurface samples from mounds near risers 1 and 5. These two types of samples formed the basis for designing the three Tank 5F composite materials (Tank 5F- Composite sample \# 1, Tank 5F- Composite sample \# 2 and Tank 5F- Composite sample \# 3). The volume of residual material in each of the Tank 5F region was obtained by SRR and this information was used to estimate the strata volumes in the tank. These strata volumes were converted into volumetric proportions, and subsequently to the mass of residual material to be obtained from each primary sample for each composite sample ${ }^{1}$ Thus; each Tank 5F composite sample was derived from five individual Tank 5F materials as shown in Table 1.

The Tank 5F samples were analyzed in accordance with Technical Task Request number HLE-TTR-2010-004, Rev 7, and Task Technical and Quality Assurance Plan for the Analysis of the Tank 5F and Tank 6F Final Characterization Samples-SRNL-RP-201001695, Rev. 1 and Tank 5 Sampling and Analysis Plan-SRR-LWE-2010-00285, Rev. 1, November 15, 2010.

\footnotetext{
${ }^{1}$ B. Dean, “Tank 5 Composite Sample Volumetric Proportions,” SRR-CWDA-2011-00067, Rev.1 April 20, 2011.
} 
SRNL-STI-2012-00034, Rev. 1 August 3, 2012

Page 10 of 50
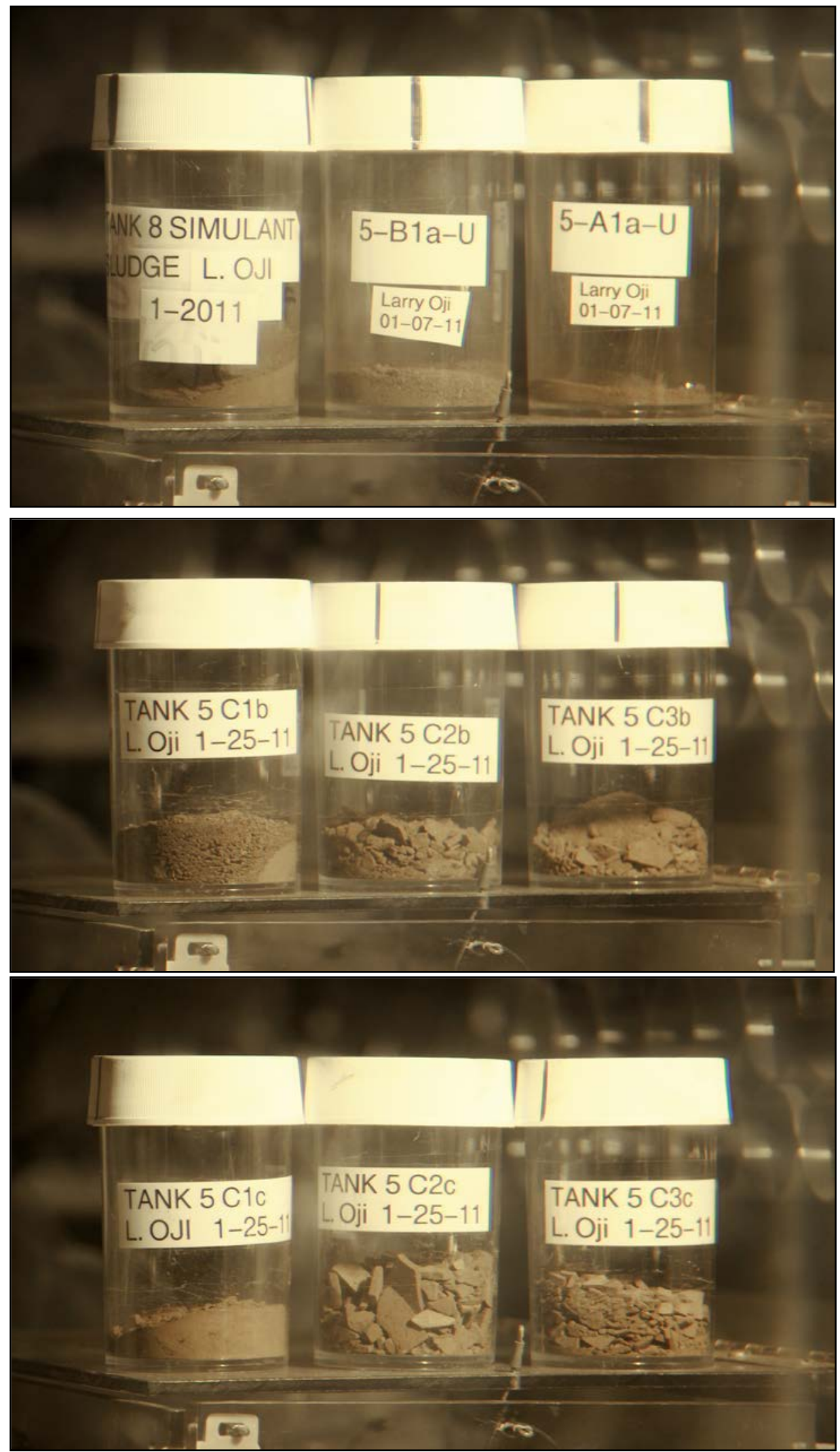

Figure 1. Photo images of “as-received” Tank 5F samples. 
SRNL-STI-2012-00034, Rev. 1

August 3, 2012

Page 11 of 50

\subsection{SAMPLING AND SAMPLE PREPARATION FOR CHARACTERIZATION}

Tank 5F samples provided by SRR for characterization came from various locations in Tank 5F as shown in Figure 2 below [HLE-TTR-2010-004].

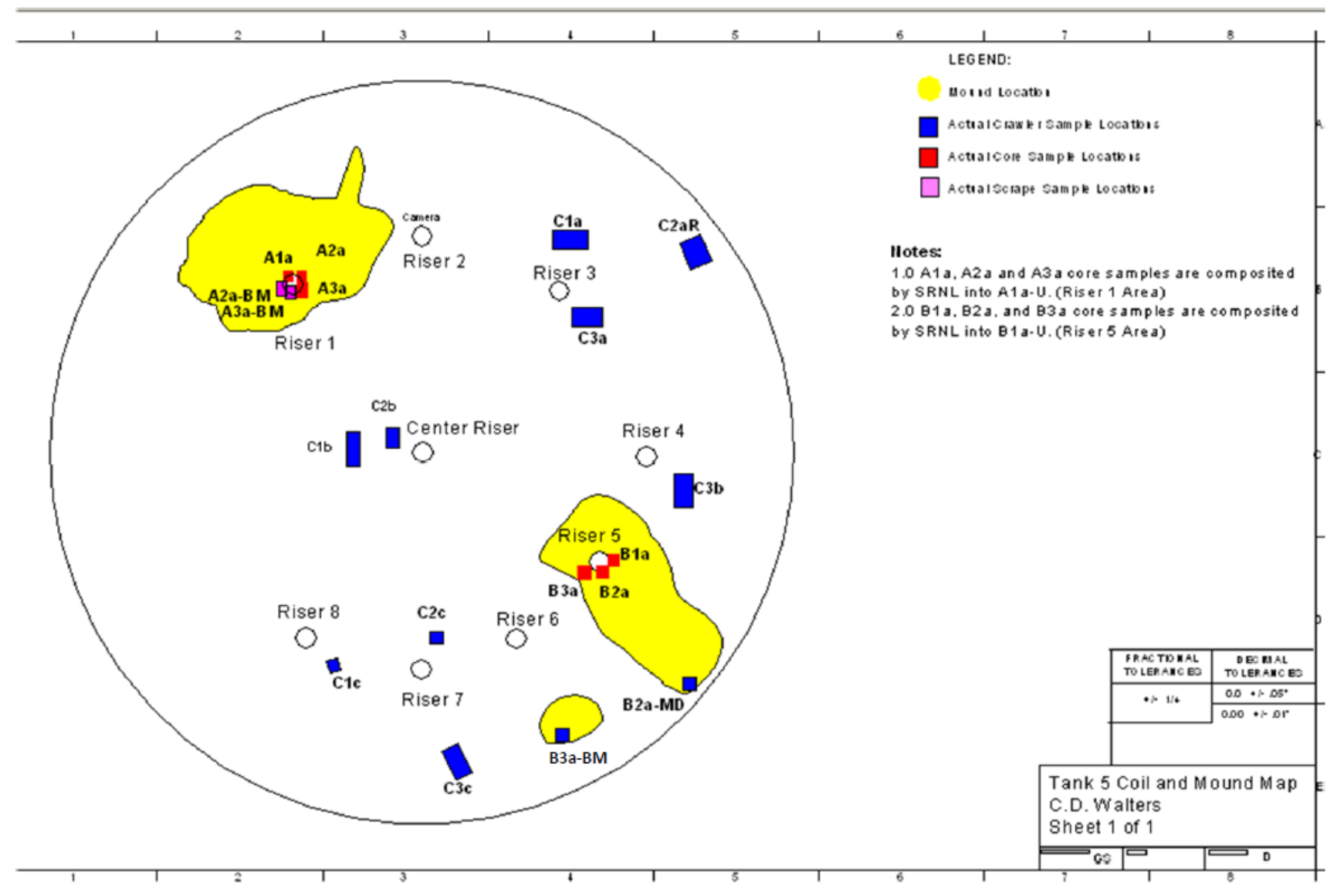

Figure 2. Tank 5F sample locations.

The last batch of Tank 5F sample containment bag received in March of 2011, when opened at SRNL shielded cell, was found to contain designated Tank 5F sample holder (5-B3a-BM) which was empty. However, some materials were found inside the secondary containment bag. The other sample container in the same containment bag (5-B2a-MD) contained some amount of Tank 5F materials. This information was brought to the attention of SRR. After their reviews, SRR concluded that both samples came from the same region of Tank $5 \mathrm{~F}$ and issued a justification and approval for SRNL to use the material found in the secondary containment bag as sample material 5-B3a-BM (B. Dean, "Tank 5F samples 5-B2a-MD and 5-B3a-BM Justification” SRR-CWDA-2011-00100 Rev. 0, May19, 2011).

These Tank 5F samples were fairly dry and needed no further air drying in the shielded cells before preparation for compositing. The individual "as-received" materials were weighed and their "as-received" dry bulk densities determined prior to preparing each sample for 
characterizations. Each Tank 5F sample was homogenized to promote particle size reduction due to the presence of chunks of solids. Homogenizing each sample involved grinding with a mortar and pestle and then passing the powder through a sieve pan with 850 micron openings (mesh 18). Samples which did not go through the sieve were ground with mortar and pestle until they were small enough to go through the sieve. The bulk density of each homogenized sample was determined followed by the blending of proportional amounts of the samples by weight to form three composite Tank 5F samples (See Table 1). The bulk density of each of the three composite samples was then determined by the process described in Appendix B. A reference simulant sludge sample, based on Tank 8 sample chemistry [See Appendix A-1], was air-dried in a clean laboratory and the resulting sludge cake ground and homogenized with a mortar and pestle. The bulk density of this reference Tank 8 sludge was determined both inside the shielded cell along with the Tank 5F samples and outside the cell in a clean laboratory hood. These Tank 8 sludge simulant bulk density values were used to verify how well the reference bulk densities could be reproduced both inside (using remote handling via manipulators) and outside of the shielded cell.

SRR determined the composite sample volumetric percent as shown in Table 1 [B. Dean, “Tank 5 Composite Sample Volumetric Proportions," SRR-CWDA-2011-00067, Rev.1 April 20, 2011]. These individual sample proportional location volumes, along with the homogenized sample bulk densities (Table 2), were used to calculate each sample's mass per composite volume and totaled. The total provided the composite density and the required weight from each of the fifteen Tank 5F sample material to make the three 70-gram composite Tank 5F samples as shown in Table 3. The Tank 5F sample with sample identification number 5-A1a-U, designated for sample composition \# 1 as shown in Tables 1 and 3, did not have sufficient material for composition to meet the $70 \mathrm{~g}$ requirement. The most that could be proportionally composited using available amount of sample 5-A1a-U (15.96 g) was $29.8 \mathrm{~g}$. The weight percent solid of the three Tank 5F composite materials was also determined as shown in Table 4. All bulk density data for the "as-received", homogenized and composited Tank 5F samples are presented in Appendices A-4 and A-5. Appendix A-6 shows the amount of discrete and composite Tank 5F samples left after all samples digestions and analyses. The weight percent solid determination method is described in Appendix B.

Table 1. Composite Samples Volumetric Distribution

\begin{tabular}{|l|l|l|l|l|l|l|}
\hline & \multicolumn{3}{|c|}{ Composite Samples } \\
\hline $\begin{array}{c}\text { Composite sample } \\
\text { number }\end{array}$ & \multicolumn{2}{|c|}{$\# \mathbf{1}$} & \multicolumn{2}{c|}{$\# \mathbf{2}$} & \multicolumn{2}{c|}{$\# 3$} \\
\hline Riser 1 & $50 \%$ & $5-\mathrm{A} 1 \mathrm{a}-\mathrm{U}$ & $55 \%$ & $5-\mathrm{A} 2 \mathrm{a}-\mathrm{BM}$ & $44 \%$ & 5-A3a-BM \\
\hline Riser 5 & $42 \%$ & $5-\mathrm{B} 2 \mathrm{a}-\mathrm{MD}$ & $38 \%$ & $5-\mathrm{B} 3 \mathrm{a}-\mathrm{BM}$ & $43 \%$ & 5-B1a-U \\
\hline \multirow{3}{*}{ Remainder of Tank } & $2.67 \%$ & $5-\mathrm{C} 1 \mathrm{a}$ & $2.33 \%$ & $5-\mathrm{C} 1 \mathrm{~b}$ & $4.33 \%$ & $5-\mathrm{C} 1 \mathrm{c}$ \\
\cline { 2 - 8 } & $2.67 \%$ & $5-\mathrm{C} 2 \mathrm{~b}$ & $2.33 \%$ & $5-\mathrm{C} 2 \mathrm{c}$ & $4.33 \%$ & 5-C2a \\
\cline { 2 - 8 } & $2.67 \%$ & $5-\mathrm{C} 3 \mathrm{c}$ & $2.33 \%$ & $5-\mathrm{C} 3 \mathrm{a}$ & $4.33 \%$ & 5-C3b \\
\hline Total & $100 \%$ & & $100 \%$ & & $100 \%$ & \\
\hline
\end{tabular}


SRNL-STI-2012-00034, Rev. 1

August 3, 2012

Page 13 of 50

Table 2. Tank 5F Sample Bulk Densities

\begin{tabular}{|c|c|c|c|c|}
\hline Tank 5F Sample ID & $\begin{array}{l}\text { “As-received" } \\
\text { Sample Density } \\
\text { Average, g/mL }\end{array}$ & $\begin{array}{l}\text { "Homogenized" } \\
\text { Sample Density } \\
\text { Average, g/mL }\end{array}$ & $\begin{array}{c}\text { Composite Sample } \\
\text { Density Average, } \\
\text { g/mL } \\
\end{array}$ & Comments \\
\hline 5-C1a & 0.91* & $1.04 \pm 0.04$ & NA & Limited amount of sample \\
\hline 5-C1b & $1.21 \pm 0.09$ & $1.11 \pm 0.01$ & NA & \\
\hline 5-C1c & $\mathbf{0 . 9 7} \pm 0.10$ & $0.95 \pm 0.07$ & NA & $\begin{array}{l}\text { Flaky and chunky } \\
\text { “As-received” sample }\end{array}$ \\
\hline 5-C2a & $\mathbf{0 . 8 5} \pm 0.02$ & $1.02 \pm 0.04$ & NA & \\
\hline 5-C2b & $\mathbf{0 . 8 7} \pm 0.06$ & $\mathbf{0 . 9 7} \pm 0.03$ & NA & $\begin{array}{c}\text { Flaky and chunky } \\
\text { “As-received” sample }\end{array}$ \\
\hline 5-C2c & $\mathbf{0 . 8 4} \pm 0.07$ & $0.93 \pm 0.04$ & NA & $\begin{array}{l}\text { Flaky and chunky } \\
\text { “As-received” sample }\end{array}$ \\
\hline 5-C3a & $\mathbf{1 . 0 5} \pm 0.01$ & $1.11 \pm 0.04$ & NA & \\
\hline 5-C3b & $\mathbf{1 . 1 7} \pm 0.05$ & $1.03 \pm 0.06$ & NA & \\
\hline 5-C3c & $\mathbf{0 . 8 5} \pm 0.04$ & $0.96 \pm 0.03$ & NA & $\begin{array}{c}\text { Flaky and chunky } \\
\text { “As-received” sample }\end{array}$ \\
\hline 5-A1a-U & $1.45 \pm 0.01$ & $1.43 \pm 0.02$ & NA & \\
\hline 5 -B1a-U & $1.47 \pm 0.01$ & $1.44 \pm 0.01$ & NA & \\
\hline 5-A2a-BM & $1.22 \pm 0.10$ & $1.25 \pm 0.01$ & NA & \\
\hline 5 -АЗа-ВМ & $\mathbf{1 . 0 9} \pm 0.02$ & $\mathbf{1 . 0 5} \pm 0.00$ & NA & \\
\hline 5-B2a-MD & $1.33 \pm 0.03$ & $1.16 \pm 0.03$ & NA & \\
\hline 5-BЗа-ВM & $\mathbf{1 . 0 5} \pm 0.09$ & $1.24 \pm 0.03$ & NA & \\
\hline $\begin{array}{c}\text { Reference Tank } 8 \\
\text { Simulant }\end{array}$ & NA & $1.45 \pm 0.04$ & & $\begin{array}{l}\text { Value is within } 10 \% \text { of out } \\
\text { of cell determination }(1.60 \\
\pm 0.03 \mathrm{~g} / \mathrm{mL})\end{array}$ \\
\hline Composite sample \#1 & NA & NA & $1.41 \pm 0.01$ & \\
\hline Composite sample \#2 & NA & NA & $\mathbf{1 . 3 4} \pm 0.03$ & \\
\hline Composite sample \#3 & NA & NA & $1.31 \pm 0.01$ & \\
\hline
\end{tabular}

*The “As-received” density values are suspect and may in some cases have large uncertainty values. Problems were encountered in determining the volumes of these samples in calibrated PMP beakers used. Most of the samples contained large chunky pieces, which made it difficult to determine acceptable sample volumes. 
Table 3. Tank 5F sample compositions for Composite samples 1, 2 and 3.

\begin{tabular}{|c|c|c|c|c|c|c|c|}
\hline $\begin{array}{l}\text { Composite } \\
\text { Sample IDs }\end{array}$ & $\begin{array}{l}\text { Material } \\
\text { Available, g }\end{array}$ & $\begin{array}{l}\text { Proportional } \\
\text { Sample location } \\
\text { volume, \% }\end{array}$ & $\begin{array}{l}\text { As-received } \\
\text { density, } \mathrm{g} / \mathrm{mL}\end{array}$ & $\begin{array}{l}\text { Wt. } \\
\text { Fraction }\end{array}$ & $\begin{array}{l}\text { Required Wt. } \\
\text { of material to } \\
\text { make } 70 \mathrm{~g} \\
\text { composite }\end{array}$ & $\begin{array}{l}\text { Optional for } \\
\text { composite } \\
\text { Sample \#1** }\end{array}$ & $\begin{array}{l}\text { Amount } \\
\text { Weighed,g }\end{array}$ \\
\hline \multicolumn{8}{|l|}{$\begin{array}{l}\text { Composite } \\
\text { Sample \#1 }\end{array}$} \\
\hline 5-A1a-U & 15.962 & 50 & 1.45 & 0.54 & 37.49 & 15.96 & 15.96 \\
\hline 5-B2a-MD & 75.784 & 42 & 1.33 & 0.41 & 28.88 & 12.26 & 12.310 \\
\hline 5-C1a & 21.832 & 2.67 & 0.91 & 0.02 & 1.26 & 0.53 & 0.530 \\
\hline 5-C2b & 49.964 & 2.67 & 0.87 & 0.02 & 1.20 & 0.51 & 0.510 \\
\hline 5-C3c & 61.402 & 2.67 & 0.85 & 0.02 & 1.17 & 0.50 & 0.530 \\
\hline Mass sum & & 100 & 1.35 & 1.0 & 70.00 & 29.8 & 29.84 \\
\hline \multicolumn{8}{|l|}{$\begin{array}{l}\text { Composite } \\
\text { Sample \#2 }\end{array}$} \\
\hline 5-A2a-BM & 278.324 & 55 & 1.22 & 0.59 & 41.12 & & 41.174 \\
\hline 5-ВЗа-ВМ & 156.933 & 38 & 1.05 & 0.35 & 24.45 & & 24.412 \\
\hline 5-C1b & 70.309 & 2.33 & 1.21 & 0.02 & 1.73 & & 1.734 \\
\hline 5-C2c & 78.696 & 2.33 & 0.84 & 0.02 & 1.20 & & 1.218 \\
\hline 5-C3a & 98.893 & 2.33 & 1.05 & 0.02 & 1.50 & & 1.521 \\
\hline Mass sum & & 100 & 1.14 & 1.0 & 70.00 & & 70.006 \\
\hline \multicolumn{8}{|l|}{$\begin{array}{l}\text { Composite } \\
\text { Sample \#3 }\end{array}$} \\
\hline 5-АЗа-ВМ & 200.41 & 44 & 1.09 & 0.39 & 27.05 & & 27.008 \\
\hline 5-B1a-U & 39.596 & 43 & 1.47 & 0.51 & 35.65 & & 35.654 \\
\hline 5-C1c & 43.266 & 4.33 & 0.97 & 0.03 & 2.37 & & 2.373 \\
\hline 5-C2a & 47.696 & 4.33 & 0.85 & 0.03 & 2.08 & & 2.080 \\
\hline 5-C3b & 54.742 & 4.33 & 1.17 & 0.04 & 2.86 & & 2.867 \\
\hline Mass sum & & 100 & 1.42 & 1.0 & 70.00 & & 70.005 \\
\hline
\end{tabular}

Table 4. Weight Percent Solids for Tank 5F Composite Samples

\begin{tabular}{|c|c|c|}
\hline Tank 5F Sample ID & Wt\% solids & Comments \\
\hline Tank 5F Composite No. 1 & $95.7 \pm 0.2$ & \\
\hline Tank 5F Composite No. 2 & $96.7 \pm 0.3$ & \\
\hline Tank 5F Composite No. 3 & $96.4 \pm 0.4$ & \\
\hline Tank 8 Simulant sludge & $89.2 \pm 0.4$ & \\
\hline $\begin{array}{l}\text { 5\% Reference } \mathrm{NaCl} \\
\text { Salt solution }\end{array}$ & $4.80 \pm 0.1$ & $\begin{array}{l}\text { Reference target weight percent } \\
\qquad \mathrm{NaCl} \text { solid }=4.9 \%\end{array}$ \\
\hline
\end{tabular}


Because of the inherent risk of cross-contamination of these samples in the shielded cells environment, certain actions were taken to minimize the risks. Actions taken to control cross-contaminations in the cell included wiping down the cell (cell decontaminated), covering the cell floor, and changing manipulator fingers prior to initiating work. Additionally, blanks were processed with samples to evaluate potential issues from methods.

\subsection{Blank Evaluations and Reference Materials}

Two types of reference matrices were used during the characterization of Tank 5F samples. The first reference material was an analyzed reference glass (ARG) which was stored outside the shielded cells but processed in the shielded cells along with the samples during sample preparations. The second was a dried Tank 8 simulant sludge, which was exposed to the shielded cell radiological environment in which the Tank 5F radionuclide material was processed prior to analysis. The elemental chemical composition of the Tank 8 simulant sludge and analyzed reference glass are presented in Appendices A-1 and A-2. Distilled and de-ionized water was used as the liquid reagent media and blanks in all cell digestion cases.

The absence of radionuclides in these reference materials allowed the materials to additionally be utilized as blanks for radiochemical analyses.

Prior to the processing of the Tank 5F samples, which normally involved the opening of selected samples to be blended together, two in-cell reference Tank 8 simulant sludge samples in 250-mL capacity poly-bottles were placed at strategic locations in the shielded cell. Each simulant sludge reference sample container contained about 20 grams of Tank 8 simulant sludge. The containers were opened when the Tank 5F samples were being processed or air dried and closed at the end of each day of work in the cell. At the end of each Tank 5F sample preparations or digestion (aqua regia and peroxide fusion digestions), the Tank 8 simulant sludge reference material was also prepared in a manner similar to that for the preparation of Tank 5F samples and submitted for the same analyses as the actual samples from Tank 5F. Additional analytical blanks were run for each of the methods.by Analytical Development.

\subsection{Leaching Characterization of Tank 5F Solids}

Known amounts of homogenized Tank 5F composite solids were leached with distilled and de-ionized water in triplicate. An average of $1.17 \pm 0.06$ grams of the composite solids was leached with an average of $50.01 \pm 0.01$ grams of distilled and de-ionized water. In this process each solid fraction was thoroughly mixed with the given amount of distilled and deionized water, and the mixture was hand agitated (shielded cell manipulator) for a total of about five minutes and left to stand for another 24 hours before another agitation and filtering of the mixture using a 0.45 micron Nalgene filter unit. The filtrate from the mixture was analyzed in triplicate for anion components as required. Thus, only surface-bound and water soluble constituents are assumed to be accounted for in the leachate analyses. 


\subsection{RESULTS}

Page 16 of 50

Appendix A-0 contains the SRNL Analytical Development Laboratory Information Management System (LIMS) numbers for tracking the analytical data presented in this report.

Details of most of the analytical methodologies including weight percent solids and density determinations applied in Tank 5F sample characterizations are summarized in Appendix B. It is worth pointing out that many digestion methods were performed in the shielded cells prior to taking representative sample aliquots out of the cells for analyses. These digestions and other methods in the cells included digestions for all the "challenging" radionuclide analyses, aqua regia digestions, peroxide fusion digestions and digestions for Th-229/230 analyses. Additionally, new methods were developed, specifically tailored for the presence of oxalic acid and other components, for characterization of Tank 5F radionuclides. These methods are summarized in Appendix B.

In the Tank 5F composite sample characterization results presented below, values preceded by "<” (less than sign) indicate values were below minimum detection limits, and values proceeded by " $\leq$ " (less than or equal to sign) indicate that for replicates, at least one of the analysis values was above the instrument or method detection limit. Thus, where replicate analyses were both above and below the detection limit, the average of all replicates above and below the detection limit is given and a " $\leq$ " sign precedes the average value. The standard deviation values were calculated only for values that were above the detection limits. The minimum detectable activity (MDA) is defined as the value above which instrument signal can be considered real and the upper limit (UL) is defined as activity observed but biased high due to spectral interference or blank contamination. The detection limit (DL) as used in mass spectrophotometer or ICP-ES analyses is equivalent to three times the standard deviation of the blank measurements.

The one sigma percent uncertainty for each major radionuclide, as reported in the tables, is based on the pooled estimate derived from the individual uncertainties for each replicate measurement for that radionuclide $\left[\operatorname{SQRT}\left(\left(\operatorname{SUMSQ}\left(\mathrm{x}_{\mathrm{i}}\right) / \mathrm{n}\right)\right)\right]$, where $\mathrm{n}$ is the number of replicates and $\mathrm{x}_{\mathrm{i}}$ is the individual uncertainty associated with each radionuclide for each run. Here it is assumed that the radio-analytical processes, be it counting or other techniques, are of the same precision for each individual measurement.

Occasionally, situations were encountered where the samples prepared and analyzed in triplicate gave mixed results with one or two of the triplicate analyses results being less than the MDA. In these cases, the reporting of the one sigma percent uncertainty is presented in a different format. In this situation, the individual percent uncertainty associated with each run for that radionuclide is reported along with MDA or upper limit values as indicated by the analytical method. For example, under the one sigma percent uncertainty column for a radionuclide in Table 12, the 8.0/MDA designation implies that the one sigma percent uncertainty for I-129 in runs 1 and 3 of the analyses is reported with values above the detection limit and thus has a pooled one sigma percent uncertainty of 8 percent. The measurement which was below the detection limit [I-129, run 2; with no percent uncertainty value assigned)] is assigned MDA, DL or upper limit designation. In some cases, especially with the radionuclides (See Th-229/230 in Table 11), the one sigma measurement uncertainty 
may be higher than $100 \%$. In such a situation, the reported value is barely above the magnitude of the minimum detection activity (MDA) for that radionuclide, which leads to a higher uncertainty in the analytical result.

To verify the absence of sample contamination during processing, analytical blank (reagent blanks and Tank 8 simulant sludge) results were compared to sample analytical results (See second column blank results for most radionuclide as presented in each Table). The blank analytical results for the different species of interest are all well below the sample analytical results or below a measureable limit. Thus, there were no measurable cross contamination issues either from the environment of the shielded cell staging and operation areas or the reagents used in sample preparations.

The reporting units for all radionuclides including PF and AQR digestion analytical results are presented per gram of composite Tank 5F sample. These composite Tank 5F samples were digested and characterized without further processing such as drying. Correction for water content as determined by sub-sample drying at $110{ }^{\circ} \mathrm{C}$, if required (original "as received" basis to dry basis), can be accomplished through the use of the dry solid weight percent (wt \%) values as shown in Table 4 for each composite sample. For example, $\mu \mathrm{Ci} / \mathrm{g}$ dried solids $=[\mathrm{x} \mu \mathrm{Ci} / \mathrm{g}$ of "as-received solids * (100 g of "as-received solids)/95.7g dried solids]; using composite sample 1 in Table 4.

The one sigma measurement uncertainty value for all of the anions and transition metals reported here is 20 percent. Leaching results are presented per gram of the "homogenized and composite” Tank 5F composite samples.

Tables 5-7 contain inorganic constituent analytical results for the three composite Tank 5F samples, while Tables 8-10 show the water soluble anion constituents for the Tank 5F composite sample. Tables 11-13 contain the analytical results for the standard radiological constituents for the three composite Tank 5F samples, while Tables 14-16 show the analytical results for the "challenging” radionuclide constituents.

\subsection{Data Quality and Presentations for Routine Radionuclide Constituents}

The ICP-MS results are given for each atomic mass and, in most cases each mass number represents only one isotope. An example of an exception is mass 238, since both uranium and plutonium are represented by this mass number. However, since the mass contribution of U-238 is significantly greater than that of Pu-238, the 238 signal is used to quantify U238, not Pu-238. For this reason, Pu-238 was determined by PUTTA (chemical separation coupled with alpha spectroscopy). See Appendix B for summaries of the methods. In cases where ICP-MS and radiochemistry data give similar results for a species, radiochemistry is typically selected due to better sensitivity and precision.

While many of the minimum detection limits (MDL), as specified in the TTR and TTQAP were met for the species characterized for Tank 5F composite samples, some were not met. In a number of cases, the relatively high levels of radioactive species of the same element or a chemically similar element precluded the ability to measure an isotope to lower levels. For example, the high activities of Am-241 and Cm-244 in the sample matrix raised the alpha 
spectroscopy instrumental backgrounds for Cm-243, having a detrimental effect on the detection limit for that isotope. The 2.6 year half-life Pm-147 co-extracts with the 90 year half-life Sm-151. Both have overlapping beta spectra, with slightly higher continuum beta end-point energy for Pm-147. The Sm-151 levels in these composite Tank 5F samples were relatively high, substantially raising the detection limit achievable for Pm-147. A number of gamma emitting radionuclides were analyzed using a Cs-137 removed gamma analysis; Cesium-137 was expected to be the main contributor to background levels which would lower the sensitivity of the gamma analysis for other species. While that was true, the samples also contained significant quantities of other gamma emitting isotopes (i.e. Co-60, Eu-154, Eu-155, etc...) which raised the background and thus the detection limits for gamma emitting species not observed (i.e. Nb-94, Sb-125, etc...).

For the Th-229/Th-230 analyses, the Tank 5F Th-230 sample activities were substantially higher than the activities of the Th-229 tracer used to trace the analyses. This resulted in a large uncertainty in the measurement of the tracer recovery, which translated into a large uncertainty in the measurement of the Th-229 and Th-230 activities present in the samples.

\subsection{Data Quality and Presentations for Elemental Constituents}

The reference materials for the elemental analyses results presented in Tables 5-7 were ARG and dried Tank 8 simulant sludge. Appendices A-1 and A-2 contain the elemental analytical results for the two reference matrices in comparison to the known values for these reference materials ${ }^{2}$.

A comparison of the laboratory results for the cations present in the simulant sludge, with potassium being the exception, shows that our laboratory results are not significantly different from the known reference values for these cations. The percent relative deviation (\%RD defined as [difference/mean]*100) for each of the 16 constituent cations of this simulant sludge material is less than $12 \%$. Only potassium analysis had a \%RD greater than 25\%. Similarly, looking at the analytical results for the 17 elemental constituents of the ARG reference sample [Appendix A-2], only strontium and zinc analyses result are above $15 \%$ RD.

The one liter reference simulant sludge sample used in these analyses came from batch simulant preparation process in which the sludge sample is prepared in 200 liter batches. Thus, using only one liter from this batch sample may not be representative sampling. Hence, the difference in potassium concentration measured in comparison to the expected nominal value may be attributed to representative subsampling. Overall, the laboratory analytical results from these two reference materials for the constituent elements are quite comparable to the expected or known concentrations.

\footnotetext{
2 C. J Coleman, R. A. Dewberry, M. F. Bryant and J.J Gemmill,” SRL's performance in Round Robin \#6Analyses of Simulated Defense Waste Glass', WSRC-TR-91-187, Rev. 0, May 31, 1999, D. Koopman,”Tank 8, Drum1, Sludge simulant, SRTC mobile Lab. ID \# 20000616,” July 26, 2000 and M. R. Poirier,“Tank 40 and Tank 8 sludge feed simulants” SRTC-WHM-2000, Rev.2, June 2000.
} 
SRNL-STI-2012-00034, Rev. 1

August 3, 2012

Page 19 of 50

To compare Tank 5F composite sample elemental analytical results by inductively coupled plasma-mass spectrophotometer (ICP-MS) with result by inductively coupled plasmaemission spectroscopy (ICP-ES) [data presented here for the elemental composition are based solely on ICP-ES], the concentration of select cations (natural $\mathrm{Cd}$, Ba and La) were calculated from ICP-MS information and the resulting concentration values compared with the ICP-ES corresponding results presented in this report. Typical calculations are shown in Appendix A-2 for cadmium, barium and lanthanum. The average percent relative deviation between ICP-MS and ICP-ES analytical results for La, Cd and Ba are, respectively, 4.9, 29 and $9.9 \%$. These comparison results are summarized in Appendix A-2 and show that ICPES analytical results are the same order of magnitude as the ICP-MS data for these select cations.

\subsection{Data Quality and Presentations for Non-Routine Radionuclide Analytes.}

Some radiochemical analyzes are considered "challenging” when dealing with radionuclides that are not present in easily measurable concentrations with existing standard methods and thus require new method development to meet the low detection limit requirements. The analytical results for some of the "challenging" to analyze isotopes, (Al-26, Cl-36, K-40, Nb94, Sn-126, Sb-126 and Sb-126m, Pd-107, Eu-152, Pt-193, Ra-226 and Ac-227), are presented slightly differently. Since analyses for these challenging analytes are confirmatory in nature, special emphasis was placed on achieving these target detection limits for at least one composite sample. Thus, only one replicate per sample is required for these analytes and for a given analyte, if all sample analysis results were below detection limits, then only the lowest detection level obtained was reported as summarized in Tables 14-16.

In some instances the analyses were not performed and reported for all three composite Tank 5F samples in triplicate, partly because of challenging analytical separation issues associated with the different methods developed for these analytes (specific methods are provided in Appendix B). Some of the development methods evaluated were unsuccessful even with extra distillation/separation and longer counting efforts. Thus, the customer specified detection limits for these challenging radionuclide species were not consistently met in the three Tank 5F composite samples as presented in detail in Appendix A-3.

The customer specified detection limits for Al-26, Eu-152, Sn-126, Sb-126, and Sb-126m were not met in any of the three Tank 5F composite samples as summarized in Tables 14-16. Analyses results obtained for the three Tank 5F composite samples for Cl-36 and Ac-227 were all upper limit values. The presence of high concentrations of stable metals and radionuclides described in section 3.1 created a challenging matrix, which limited the ability of the methods to achieve minimum detection limits as presented in Tables 14-16. These results were reviewed with the customer, who accepted the given results as presented [SRRCWDA-2012-00013].

The detection limits for Nb-94 and Pt-193 were met in the analyses of Tank 5F composite sample No. 1, while the detection limits obtained for Ra-226, Ac-227, Cl-36 and K-40 for Tank 5F composite sample No. 1 were about the same order of magnitude as the customer desired detection limits of $10^{-3} \mathrm{uCi} / \mathrm{g}$ (Table 14). Analytical results for Tank 5F composite sample No. 2, shows that the detection limits for Nb-94, Pt-193, Ra-226, and Ac-227 were 
met, while analytical results for Cl-36 and K-40 were about the same order of magnitude as the customer desired detection limits. The analytical results for Tank 5F composite sample No. 3 shows that the customer specified detection limits, as summarized in Table 16, were met for K-40, Nb-94 and Ra-226, while the detection limits for Cl-36, Pt-193 and Ac-227 were about the same order of magnitude as the customer desired detection limits. Meanwhile, a review of blank analytical data shows that analyses performed for Cl-36 blanks in the Tank 5F composite samples show evidence of beta activity. This is an indication that counts from the composite samples for Cl-36 could have been due to beta cross contamination caused by sample manipulation. Thus, it can be concluded that the limited measured activity assigned to Cl-36 may not be due to the presence of Cl-36 in all three composite Tank 5F samples.

The Pu-241 liquid scintillation analyses had traces of high energy beta activity present in addition to the Pu-241 beta. As a consequence, the Pu-241 values reported are flagged as upper limits as the $\mathrm{Pu}-241$ results had a small positive bias (about 10\%) resulting from spillover of the higher energy beta emitter's activity into the Pu-241 lower energy beta window.

Where the use of tracers showed extremely poor or no recovery at all, as in the case of using stable selenium as a carrier with the blank for selenium-79 analyses, no results are presented in the Tables, but instead a "no yield" is indicated. This is especially the case with blank and reference samples for routine radionuclide analytes and "challenging” analytes. 
SRNL-STI-2012-00034, Rev. 1

August 3, 2012

Page 21 of 50

Table 5. Elemental Constituents in Tank 5F Composite Sample \# 1, mg/g sample *

\begin{tabular}{|c|c|c|c|c|c|}
\hline Analyte & Tank 5, Run1 & Tank 5, Run 2 & Tank 5, Run 3 & Average & STDEV \\
\hline $\mathrm{Ag}$ & 2.01E-01 & $2.38 \mathrm{E}-01$ & 2.73E-01 & 2.37E-01 & $3.60 E-02$ \\
\hline $\mathrm{Al}$ & $4.06 \mathrm{E}+00$ & $4.42 \mathrm{E}+00$ & $8.70 \mathrm{E}+00$ & $5.73 E+00$ & $2.58 E+00$ \\
\hline $\mathrm{B}$ & $1.40 \mathrm{E}+00$ & $1.30 \mathrm{E}+00$ & $1.20 \mathrm{E}+00$ & $1.30 \mathrm{E}+00$ & $1.00 E-01$ \\
\hline $\mathrm{Ba}$ & $1.74 \mathrm{E}+00$ & $1.97 \mathrm{E}+00$ & $2.07 \mathrm{E}+00$ & $1.93 E+00$ & $1.69 E-01$ \\
\hline $\mathrm{Be}$ & $1.30 \mathrm{E}-02$ & $1.21 \mathrm{E}-02$ & $1.12 \mathrm{E}-02$ & 1.21E-02 & $9.00 E-04$ \\
\hline $\mathrm{Ca}$ & $1.43 \mathrm{E}+00$ & $1.38 \mathrm{E}+00$ & $1.43 \mathrm{E}+00$ & $1.41 E+00$ & $2.89 E-02$ \\
\hline $\mathrm{Cd}$ & 8.13E-02 & $9.16 \mathrm{E}-02$ & 9.69E-02 & 8.99E-02 & $7.93 E-03$ \\
\hline $\mathrm{Ce}$ & $1.97 \mathrm{E}+00$ & $2.59 \mathrm{E}+00$ & $3.06 \mathrm{E}+00$ & $2.54 \mathrm{E}+00$ & $5.47 E-01$ \\
\hline Co & $1.87 \mathrm{E}-01$ & 2.12E-01 & 2.39E-01 & 2.13E-01 & $2.60 E-02$ \\
\hline $\mathrm{Cr}$ & $1.39 \mathrm{E}+00$ & $1.04 \mathrm{E}+00$ & $9.68 \mathrm{E}-01$ & $1.13 E+00$ & $2.26 E-01$ \\
\hline $\mathrm{Cu}$ & $6.84 \mathrm{E}-01$ & 7.16E-01 & 7.60E-01 & $7.20 \mathrm{E}-01$ & $3.82 E-02$ \\
\hline $\mathrm{Fe}$ & $5.23 \mathrm{E}+02$ & $4.88 \mathrm{E}+02$ & $4.52 \mathrm{E}+02$ & $4.88 \mathrm{E}+02$ & $3.55 E+01$ \\
\hline Gd & 1.93E-01 & 1.93E-01 & 1.93E-01 & 1.93E-01 & $0.00 E+00$ \\
\hline $\mathrm{K}$ & $2.94 \mathrm{E}-01$ & 3.68E-01 & 3.64E-01 & 3.42E-01 & $4.16 E-02$ \\
\hline $\mathrm{La}$ & $1.33 \mathrm{E}+00$ & $1.38 \mathrm{E}+00$ & $1.45 \mathrm{E}+00$ & $1.39 E+00$ & $6.03 E-02$ \\
\hline $\mathrm{Li}$ & 4.00E-01 & 5.30E-01 & 6.09E-01 & 5.13E-01 & $1.06 E-01$ \\
\hline $\mathrm{Mg}$ & 4.54E-01 & 4.88E-01 & 5.27E-01 & 4.90E-01 & $3.65 E-02$ \\
\hline $\mathrm{Mn}$ & $3.11 \mathrm{E}+01$ & $3.43 \mathrm{E}+01$ & $3.80 \mathrm{E}+01$ & $3.45 \mathrm{E}+01$ & $3.45 E+00$ \\
\hline Mo & 4.87E-02 & $5.10 \mathrm{E}-02$ & $5.06 \mathrm{E}-02$ & 5.01E-02 & $1.23 E-03$ \\
\hline $\mathrm{Na}$ & $3.60 \mathrm{E}+00$ & $3.55 \mathrm{E}+00$ & $3.61 \mathrm{E}+00$ & $3.59 \mathrm{E}+00$ & $3.21 E-02$ \\
\hline $\mathrm{Ni}$ & $4.54 \mathrm{E}+01$ & $5.63 \mathrm{E}+01$ & $6.34 \mathrm{E}+01$ & $5.50 \mathrm{E}+01$ & $9.07 E+00$ \\
\hline $\mathrm{P}$ & $2.26 \mathrm{E}-01$ & 2.11E-01 & 2.65E-01 & 2.34E-01 & $2.79 E-02$ \\
\hline $\mathrm{Pb}$ & $3.88 \mathrm{E}+00$ & $3.70 \mathrm{E}+00$ & $3.49 \mathrm{E}+00$ & $3.69 \mathrm{E}+00$ & $1.95 E-01$ \\
\hline $\mathrm{S}$ & $<2.70 \mathrm{E}-01$ & $<3.06 \mathrm{E}-01$ & 5.13E-01 & $\leq 3.63 \mathrm{E}-01$ & \\
\hline $\mathrm{Sb}$ & $<7.67 \mathrm{E}-01$ & $<8.68 \mathrm{E}-01$ & $<7.80 \mathrm{E}-01$ & $<8.05 \mathrm{E}-01$ & \\
\hline $\mathrm{Si}$ & $1.05 \mathrm{E}+00$ & $1.05 \mathrm{E}+00$ & $6.04 \mathrm{E}-01$ & 9.01E-01 & $2.57 E-01$ \\
\hline Sn & 4.37E-02 & $5.06 \mathrm{E}-02$ & 3.18E-02 & 4.20E-02 & $9.51 E-03$ \\
\hline $\mathrm{Sr}$ & 4.11E-01 & 3.81E-01 & 3.65E-01 & 3.86E-01 & $2.34 E-02$ \\
\hline Th & $<3.90 \mathrm{E}-01$ & $<4.40 \mathrm{E}-01$ & $<3.90 \mathrm{E}-01$ & $<4.04 \mathrm{E}-01$ & \\
\hline $\mathrm{Ti}$ & 2.22E-01 & $2.55 \mathrm{E}-01$ & 2.79E-01 & 2.52E-01 & $2.86 E-02$ \\
\hline $\mathrm{U}$ & $7.14 \mathrm{E}+00$ & $8.13 E+00$ & $9.23 \mathrm{E}+00$ & $8.17 E+00$ & $1.05 E+00$ \\
\hline $\mathrm{V}$ & $<3.40 \mathrm{E}-02$ & $<3.80 \mathrm{E}-02$ & $<3.40 \mathrm{E}-02$ & $<3.55 \mathrm{E}-02$ & \\
\hline $\mathrm{Zn}$ & 3.70E-01 & 4.11E-01 & 5.12E-01 & 4.31E-01 & $7.31 E-02$ \\
\hline $\mathrm{Zr}$ & $3.54 \mathrm{E}+00$ & $4.43 \mathrm{E}+00$ & $4.57 \mathrm{E}+00$ & $4.18 \mathrm{E}+00$ & $5.59 E-01$ \\
\hline $\mathrm{Hg}$ & $1.84 \mathrm{E}+00$ & $2.32 \mathrm{E}+00$ & $2.55 E+00$ & $2.24 \mathrm{E}+00$ & $0.362 E+00$ \\
\hline Se & $<2.00 \mathrm{E}-02$ & $<2.00 \mathrm{E}-02$ & $<2.00 \mathrm{E}-02$ & $<2.00 \mathrm{E}-02$ & \\
\hline As & $<9.44 \mathrm{E}-03$ & $<1.07 \mathrm{E}-02$ & $<9.60 \mathrm{E}-03$ & $<9.91 \mathrm{E}-03$ & \\
\hline
\end{tabular}

* The following color codes are used for the Table contents: Green for blank values, red for less than values, pink for less than or equal to values, and bold for averages. All subsequent tables have similar color code meanings. 
SRNL-STI-2012-00034, Rev. 1

August 3, 2012

Page 22 of 50

Table 6. Elemental Constituents in Tank 5F Composite Sample \# 2, mg/g sample

\begin{tabular}{|c|c|c|c|c|c|}
\hline Analyte & Tank 5 Run 1 & Tank 5 Run 2 & Tank 5 Run 3 & Average & STDEV \\
\hline $\mathrm{Ag}$ & $2.16 \mathrm{E}-01$ & $2.15 \mathrm{E}-01$ & $2.16 \mathrm{E}-01$ & 2.16E-01 & $5.77 E-04$ \\
\hline $\mathrm{Al}$ & $4.31 \mathrm{E}+00$ & $4.45 \mathrm{E}+00$ & $4.35 \mathrm{E}+00$ & $4.37 \mathrm{E}+00$ & $7.21 E-02$ \\
\hline $\mathrm{B}$ & $1.4 \mathrm{E}+00$ & $1.37 \mathrm{E}+00$ & $1.35 \mathrm{E}+00$ & $1.37 \mathrm{E}+00$ & $2.52 E-02$ \\
\hline $\mathrm{Ba}$ & $1.77 \mathrm{E}+00$ & $1.86 \mathrm{E}+00$ & $1.83 \mathrm{E}+00$ & $1.82 \mathrm{E}+00$ & $4.58 E-02$ \\
\hline $\mathrm{Be}$ & $1.29 \mathrm{E}-02$ & $1.27 \mathrm{E}-02$ & $1.26 \mathrm{E}-02$ & 1.27E-02 & $1.53 E-04$ \\
\hline $\mathrm{Ca}$ & $1.55 \mathrm{E}+00$ & $1.56 \mathrm{E}+00$ & $1.55 \mathrm{E}+00$ & $1.55 \mathrm{E}+00$ & $5.77 E-03$ \\
\hline $\mathrm{Cd}$ & 8.33E-02 & 8.73E-02 & 8.59E-02 & 8.55E-02 & $2.03 E-03$ \\
\hline $\mathrm{Ce}$ & $1.92 \mathrm{E}+00$ & $2.29 \mathrm{E}+00$ & $2.18 \mathrm{E}+00$ & $2.13 E+00$ & $1.90 E-01$ \\
\hline Co & $1.86 \mathrm{E}-01$ & $1.96 \mathrm{E}-01$ & $1.95 \mathrm{E}-01$ & 1.92E-01 & $5.51 E-03$ \\
\hline $\mathrm{Cr}$ & 9.82E-01 & 9.98E-01 & $9.78 \mathrm{E}-01$ & $9.86 \mathrm{E}-01$ & $1.06 E-02$ \\
\hline $\mathrm{Cu}$ & 6.42E-01 & $6.68 \mathrm{E}-01$ & $6.59 \mathrm{E}-01$ & 6.56E-01 & $1.32 E-02$ \\
\hline $\mathrm{Fe}$ & $5.22 \mathrm{E}+02$ & $5.15 \mathrm{E}+02$ & $5.05 \mathrm{E}+02$ & $5.14 \mathrm{E}+02$ & $8.54 E+00$ \\
\hline Gd & 1.93E-01 & 1.96E-01 & 1.95E-01 & 1.95E-01 & $1.53 E-03$ \\
\hline K & 2.93E-01 & $2.47 \mathrm{E}-01$ & $2.68 \mathrm{E}-01$ & $2.69 \mathrm{E}-01$ & $2.30 E-02$ \\
\hline $\mathrm{La}$ & $1.21 \mathrm{E}+00$ & $1.29 \mathrm{E}+00$ & $1.26 \mathrm{E}+00$ & $1.25 \mathrm{E}+00$ & $4.04 E-02$ \\
\hline $\mathrm{Li}$ & 4.15E-01 & 4.79E-01 & 4.55E-01 & $4.50 \mathrm{E}-01$ & $3.23 E-02$ \\
\hline $\mathrm{Mg}$ & 4.70E-01 & 4.87E-01 & 4.80E-01 & 4.79E-01 & $8.54 E-03$ \\
\hline $\mathrm{Mn}$ & $3.05 \mathrm{E}+01$ & $3.14 \mathrm{E}+01$ & $3.18 \mathrm{E}+01$ & $3.12 \mathrm{E}+01$ & $6.66 E-01$ \\
\hline Mo & $4.55 \mathrm{E}-02$ & 4.42E-02 & 4.56E-02 & $4.51 \mathrm{E}-02$ & $7.81 E-04$ \\
\hline $\mathrm{Na}$ & $3.6 \mathrm{E}+00$ & $3.71 \mathrm{E}+00$ & $3.71 \mathrm{E}+00$ & $3.67 \mathrm{E}+00$ & $6.35 E-02$ \\
\hline $\mathrm{Ni}$ & $4.63 \mathrm{E}+01$ & $5.17 \mathrm{E}+01$ & $4.99 \mathrm{E}+01$ & $4.93 E+01$ & $2.75 E+00$ \\
\hline $\mathrm{P}$ & 2.19E-01 & $3.21 \mathrm{E}-01$ & 3.34E-01 & 2.91E-01 & $6.30 E-02$ \\
\hline $\mathrm{Pb}$ & $3.85 E+00$ & $3.78 \mathrm{E}+00$ & $3.77 \mathrm{E}+00$ & $3.80 \mathrm{E}+00$ & $4.36 E-02$ \\
\hline$S$ & $<3.00 \mathrm{E}-01$ & $2.90 \mathrm{E}-01$ & $<3.00 \mathrm{E}-01$ & $\leq 2.96 \mathrm{E}-01$ & \\
\hline $\mathrm{Sb}$ & $<8.60 \mathrm{E}-01$ & $<8.00 \mathrm{E}-01$ & $<8.40 \mathrm{E}-01$ & $<8.40 \mathrm{E}-01$ & \\
\hline $\mathrm{Si}$ & $1.24 \mathrm{E}+00$ & $1.32 \mathrm{E}+00$ & 9.13E-01 & $1.16 \mathrm{E}+00$ & $2.16 E-01$ \\
\hline Sn & 4.41E-02 & $4.08 \mathrm{E}-02$ & 4.40E-02 & 4.30E-02 & $1.88 E-03$ \\
\hline $\mathrm{Sr}$ & $4.11 \mathrm{E}-01$ & 4.03E-01 & $4.01 \mathrm{E}-01$ & 4.06E-01 & $4.16 E-03$ \\
\hline Th & $<4.30 \mathrm{E}-01$ & $<4.00 \mathrm{E}-01$ & $<4.20 \mathrm{E}-01$ & $<4.20 \mathrm{E}-01$ & \\
\hline $\mathrm{Ti}$ & 2.3E-01 & $2.45 \mathrm{E}-01$ & $2.46 \mathrm{E}-01$ & $2.40 \mathrm{E}-01$ & $8.96 E-03$ \\
\hline $\mathrm{U}$ & $7.97 \mathrm{E}+00$ & $8.89 \mathrm{E}+00$ & $9.43 \mathrm{E}+00$ & $8.76 \mathrm{E}+00$ & $7.38 E-01$ \\
\hline $\mathrm{V}$ & $<3.80 \mathrm{E}-02$ & $<3.60 \mathrm{E}-02$ & $<3.70 \mathrm{E}-02$ & $<3.69 \mathrm{E}-02$ & \\
\hline $\mathrm{Zn}$ & 3.62E-01 & 3.81E-01 & $3.80 \mathrm{E}-01$ & 3.74E-01 & $1.07 E-02$ \\
\hline $\mathrm{Zr}$ & $3.74 \mathrm{E}+00$ & $4.07 \mathrm{E}+00$ & $3.98 \mathrm{E}+00$ & $3.93 \mathrm{E}+00$ & $1.71 E-01$ \\
\hline $\mathrm{Hg}$ & $1.92 \mathrm{E}+00$ & $2.07 \mathrm{E}+00$ & $1.98 \mathrm{E}+00$ & $1.99 \mathrm{E}+00$ & 0.076 \\
\hline Se & $<2.10 \mathrm{E}-02$ & $<2.00 \mathrm{E}-03$ & $<2.00 \mathrm{E}-03$ & $<$ 8.0E-03 & \\
\hline As & $<1.06 \mathrm{E}-02$ & $<9.91 \mathrm{E}-03$ & $<1.04 \mathrm{E}-02$ & $<1.03 \mathrm{E}-02$ & \\
\hline
\end{tabular}


SRNL-STI-2012-00034, Rev. 1

August 3, 2012

Page 23 of 50

Table 7. Elemental Constituents in Tank 5F- Composite Sample \# 3, mg/g sample

\begin{tabular}{|c|c|c|c|c|c|}
\hline Analyte & Tank 5 Run 1 & Tank 5 Run 2 & Tank 5 Run 3 & Average & STDEV \\
\hline $\mathrm{Ag}$ & $2.82 \mathrm{E}-01$ & $2.90 \mathrm{E}-01$ & $2.95 \mathrm{E}-01$ & $2.89 \mathrm{E}-01$ & $6.56 E-03$ \\
\hline $\mathrm{Al}$ & $4.58 \mathrm{E}+00$ & $4.34 \mathrm{E}+00$ & $4.59 \mathrm{E}+00$ & $4.50 \mathrm{E}+00$ & $1.42 E-01$ \\
\hline $\mathrm{B}$ & $1.27 \mathrm{E}+00$ & $1.25 \mathrm{E}+00$ & $1.25 \mathrm{E}+00$ & $1.26 \mathrm{E}+00$ & $1.15 E-02$ \\
\hline $\mathrm{Ba}$ & $2.1 \mathrm{E}+00$ & $2.11 \mathrm{E}+00$ & $2.1 \mathrm{E}+00$ & $2.10 \mathrm{E}+00$ & $5.77 E-03$ \\
\hline $\mathrm{Be}$ & $1.16 \mathrm{E}-02$ & $1.16 \mathrm{E}-02$ & 1.17E-02 & 1.16E-02 & $5.77 E-05$ \\
\hline $\mathrm{Ca}$ & $1.81 \mathrm{E}+00$ & $1.45 \mathrm{E}+00$ & $1.75 \mathrm{E}+00$ & $1.67 E+00$ & $1.93 E-01$ \\
\hline $\mathrm{Cd}$ & $9.28 \mathrm{E}-02$ & 9.37E-02 & $9.56 \mathrm{E}-02$ & $9.40 \mathrm{E}-02$ & $1.43 E-03$ \\
\hline $\mathrm{Ce}$ & $2.96 \mathrm{E}+00$ & $3.00 \mathrm{E}+00$ & $3.07 \mathrm{E}+00$ & $3.01 E+00$ & $5.57 E-02$ \\
\hline Co & $2.40 \mathrm{E}-01$ & $2.41 \mathrm{E}-01$ & $2.40 \mathrm{E}-01$ & $2.40 \mathrm{E}-01$ & $5.77 E-04$ \\
\hline $\mathrm{Cr}$ & $1.03 \mathrm{E}+00$ & $1.06 \mathrm{E}+00$ & $1.06 \mathrm{E}+00$ & $1.05 E+00$ & $1.73 E-02$ \\
\hline $\mathrm{Cu}$ & 9.54E-01 & $6.92 \mathrm{E}-01$ & $7.42 \mathrm{E}-01$ & 7.96E-01 & $1.39 E-01$ \\
\hline $\mathrm{Fe}$ & $4.66 \mathrm{E}+02$ & $4.66 \mathrm{E}+02$ & $4.65 \mathrm{E}+02$ & $4.66 \mathrm{E}+02$ & $5.77 E-01$ \\
\hline Gd & $2.04 \mathrm{E}-01$ & $2.01 \mathrm{E}-01$ & $2.02 \mathrm{E}-01$ & 2.02E-01 & $1.53 E-03$ \\
\hline $\mathrm{K}$ & 3.39E-01 & $2.67 \mathrm{E}-01$ & $4.40 \mathrm{E}-01$ & 2.83E-01 & $4.96 E-02$ \\
\hline $\mathrm{La}$ & $1.65 \mathrm{E}+00$ & $1.63 \mathrm{E}+00$ & $1.65 \mathrm{E}+00$ & $1.64 \mathrm{E}+00$ & $1.15 E-02$ \\
\hline $\mathrm{Li}$ & 5.57E-01 & $5.78 \mathrm{E}-01$ & $5.87 \mathrm{E}-01$ & $5.74 \mathrm{E}-01$ & $1.54 E-02$ \\
\hline $\mathrm{Mg}$ & $5.15 \mathrm{E}-01$ & 4.96E-01 & $5.10 \mathrm{E}-01$ & 5.07E-01 & $9.85 E-03$ \\
\hline Mn & $3.68 \mathrm{E}+01$ & $3.54 \mathrm{E}+01$ & $3.54 \mathrm{E}+01$ & $3.59 \mathrm{E}+01$ & $8.08 E-01$ \\
\hline Mo & $4.57 \mathrm{E}-02$ & $4.55 \mathrm{E}-02$ & 4.49E-02 & $4.54 \mathrm{E}-02$ & $4.16 E-04$ \\
\hline $\mathrm{Na}$ & $4.23 \mathrm{E}+00$ & $4.07 \mathrm{E}+00$ & $4.11 \mathrm{E}+00$ & $4.14 \mathrm{E}+00$ & $8.33 E-02$ \\
\hline $\mathrm{Ni}$ & $6.11 \mathrm{E}+01$ & $6.25 \mathrm{E}+01$ & $6.32 \mathrm{E}+01$ & $6.23 E+01$ & $1.07 E+00$ \\
\hline $\mathrm{P}$ & 2.95E-01 & 3.02E-01 & 2.94E-01 & 2.97E-01 & $4.36 E-03$ \\
\hline $\mathrm{Pb}$ & $3.58 \mathrm{E}+00$ & $3.60 \mathrm{E}+00$ & $3.62 \mathrm{E}+00$ & $3.60 \mathrm{E}+00$ & $2.00 E-02$ \\
\hline $\mathrm{S}$ & 3.62E-01 & 4.29E-01 & 3.25E-01 & $3.72 \mathrm{E}-01$ & $5.27 E-02$ \\
\hline $\mathrm{Sb}$ & $<8.00 \mathrm{E}-01$ & $<8.45 \mathrm{E}-01$ & $<8.50 \mathrm{E}-01$ & $<8.31 \mathrm{E}-01$ & \\
\hline $\mathrm{Si}$ & 7.99E-01 & $1.86 \mathrm{E}+00$ & $1.15 \mathrm{E}+00$ & $1.27 \mathrm{E}+00$ & $5.41 E-01$ \\
\hline Sn & $3.70 \mathrm{E}-02$ & 4.05E-02 & 4.12E-02 & $3.96 \mathrm{E}-02$ & $2.25 E-03$ \\
\hline $\mathrm{Sr}$ & 3.53E-01 & $3.47 \mathrm{E}-01$ & $3.46 \mathrm{E}-01$ & $3.49 \mathrm{E}-01$ & $3.79 E-03$ \\
\hline Th & $<4.00 \mathrm{E}-01$ & $<4.24 \mathrm{E}-01$ & $<4.30 \mathrm{E}-01$ & $<4.17 \mathrm{E}-01$ & \\
\hline $\mathrm{Ti}$ & $2.54 \mathrm{E}-01$ & 2.57E-01 & 2.66E-01 & 2.59E-01 & $6.24 E-03$ \\
\hline $\mathrm{U}$ & $10.6 \mathrm{E}+00$ & $9.79 \mathrm{E}+00$ & $9.64 \mathrm{E}+00$ & $1.00 \mathrm{E}+01$ & $5.16 E-01$ \\
\hline $\mathrm{V}$ & $<4.00 \mathrm{E}-02$ & $<3.73 \mathrm{E}-02$ & $<4.00 \mathrm{E}-02$ & $<3.66 \mathrm{E}-02$ & \\
\hline $\mathrm{Zn}$ & 6.61E-01 & 4.43E-01 & 5.03E-01 & $5.36 \mathrm{E}-01$ & $1.13 E-01$ \\
\hline $\mathrm{Zr}$ & $4.58 \mathrm{E}+00$ & $4.92 \mathrm{E}+00$ & $4.93 \mathrm{E}+00$ & $4.81 \mathrm{E}+00$ & $1.99 E-01$ \\
\hline $\mathrm{Hg}$ & $2.49 \mathrm{E}+00$ & $2.53 \mathrm{E}+00$ & $2.61 \mathrm{E}+00$ & $2.54 \mathrm{E}+00$ & $6.10 E-02$ \\
\hline $\mathrm{Se}$ & $<2.00 \mathrm{E}-02$ & $<2.10 \mathrm{E}-02$ & $<2.10 \mathrm{E}-02$ & $<.2 .0 \mathrm{E}-02$ & \\
\hline As & $<9.79 \mathrm{E}-03$ & $<1.04 \mathrm{E}-02$ & $<1.05 \mathrm{E}-02$ & $<1.01 \mathrm{E}-02$ & \\
\hline
\end{tabular}


SRNL-STI-2012-00034, Rev. 1

August 3, 2012

Page 24 of 50

Table 8. Anions Leached per gram of Tank 5F- Composite Sample \#1

\begin{tabular}{|c|c|c|c|c|c|c|}
\hline Analyte & Run-1 & Run-2 & Run-3 & Average & Std. Dev. & Unit \\
\hline $\mathrm{F}^{-1}$ & $<0.046$ & $<0.040$ & $<0.037$ & $<\mathbf{0 . 0 4 1}$ & & $\mathrm{mg} / \mathrm{g}$ \\
\hline $\mathrm{Cl}^{-1}$ & 0.046 & 0.040 & 0.037 & $\mathbf{0 . 0 4 1}$ & 0.00 & $\mathrm{mg} / \mathrm{g}$ \\
\hline $\mathrm{NO}_{3}^{-1}$ & 0.23 & 0.32 & 0.075 & $\mathbf{0 . 2 1}$ & 0.12 & $\mathrm{mg} / \mathrm{g}$ \\
\hline $\mathrm{NO}_{2}^{-1}$ & 0.046 & 0.079 & $<0.037$ & $\leq \mathbf{0 . 0 5 4}$ & & $\mathrm{mg} / \mathrm{g}$ \\
\hline $\mathrm{SO}_{4}^{-2}$ & 0.27 & 0.24 & 0.22 & $\mathbf{0 . 2 5}$ & 0.03 & $\mathrm{mg} / \mathrm{g}$ \\
\hline $\mathrm{C}_{2} \mathrm{O}_{4}^{-2}$ & 1.96 & 1.87 & 1.90 & $\mathbf{1 . 9 1}$ & 0.05 & $\mathrm{mg} / \mathrm{g}$ \\
\hline $\mathrm{PO}_{4}^{-3}$ & $<0.046$ & $<0.040$ & $<0.037$ & $<\mathbf{0 . 0 4 1}$ & & $\mathrm{mg} / \mathrm{g}$ \\
\hline $\mathrm{CHO}_{2}^{-1}$ & 0.59 & 0.56 & 0.52 & $\mathbf{0 . 5 6}$ & 0.04 & $\mathrm{mg} / \mathrm{g}$ \\
\hline
\end{tabular}

Table 9. Anions Leached per gram of Tank 5F- Composite Sample \#2

\begin{tabular}{|c|c|c|c|c|c|c|}
\hline Analyte & Run-1 & Run-2 & Run-3 & Average & Std. Dev. & Unit \\
\hline $\mathrm{F}^{-1}$ & $<0.036$ & $<0.045$ & $<0.049$ & $<\mathbf{0 . 0 4 3}$ & & $\mathrm{mg} / \mathrm{g}$ \\
\hline $\mathrm{Cl}^{-1}$ & $<0.036$ & 0.045 & 0.049 & $\leq \mathbf{0 . 0 4 3}$ & & $\mathrm{mg} / \mathrm{g}$ \\
\hline $\mathrm{NO}_{3}{ }^{-1}$ & 0.072 & 0.045 & 0.049 & $\mathbf{0 . 0 5 5}$ & 0.01 & $\mathrm{mg} / \mathrm{g}$ \\
\hline $\mathrm{NO}_{2}{ }^{-1}$ & $<0.036$ & $<0.045$ & $<0.049$ & $<\mathbf{0 . 0 4 3}$ & & $\mathrm{mg} / \mathrm{g}$ \\
\hline $\mathrm{SO}_{4}^{-2}$ & 0.14 & 0.13 & 0.15 & $\mathbf{0 . 1 4}$ & 0.01 & $\mathrm{mg} / \mathrm{g}$ \\
\hline $\mathrm{C}_{2} \mathrm{O}_{4}^{-2}$ & 2.24 & 2.42 & 2.30 & $\mathbf{2 . 3 2}$ & 0.09 & $\mathrm{mg} / \mathrm{g}$ \\
\hline $\mathrm{PO}_{4}^{-3}$ & $<0.036$ & $<0.045$ & $<0.049$ & $<\mathbf{0 . 0 4 3}$ & & $\mathrm{mg} / \mathrm{g}$ \\
\hline $\mathrm{CHO}_{2}^{-1}$ & 0.22 & 0.22 & 0.24 & $\mathbf{0 . 2 3}$ & 0.01 & $\mathrm{mg} / \mathrm{g}$ \\
\hline
\end{tabular}

Table 10. Anions Leached per gram of Tank 5F- Composite Sample \#3

\begin{tabular}{|c|c|c|c|c|c|c|}
\hline Analyte & Run-1 & Run-2 & Run-3 & Average & Std. Dev. & Unit \\
\hline $\mathrm{F}^{-1}$ & $<0.044$ & $<0.044$ & $<0.048$ & $<\mathbf{0 . 0 4 5}$ & & $\mathrm{mg} / \mathrm{g}$ \\
\hline $\mathrm{Cl}^{-1}$ & $<0.044$ & $<0.044$ & $<0.048$ & $<\mathbf{0 . 0 4 5}$ & & $\mathrm{mg} / \mathrm{g}$ \\
\hline $\mathrm{NO}_{3}^{-1}$ & 0.088 & 0.089 & 0.095 & $\mathbf{0 . 0 9 1}$ & 0.00 & $\mathrm{mg} / \mathrm{g}$ \\
\hline $\mathrm{NO}_{2}^{-1}$ & $<0.044$ & $<0.044$ & $<0.048$ & $<\mathbf{0 . 0 4 5}$ & & $\mathrm{mg} / \mathrm{g}$ \\
\hline $\mathrm{SO}_{4}^{-2}$ & 0.31 & 0.31 & 0.33 & $\mathbf{0 . 3 2}$ & 0.01 & $\mathrm{mg} / \mathrm{g}$ \\
\hline $\mathrm{C}_{2} \mathrm{O}_{4}^{-2}$ & 2.65 & 2.66 & 2.86 & $\mathbf{2 . 7 2}$ & 0.12 & $\mathrm{mg} / \mathrm{g}$ \\
\hline $\mathrm{PO}_{4}^{-3}$ & $<0.044$ & $<0.044$ & $<0.048$ & $<\mathbf{0 . 0 4 5}$ & & $\mathrm{mg} / \mathrm{g}$ \\
\hline $\mathrm{CHO}_{2}^{-1}$ & 0.40 & 0.40 & 0.38 & $\mathbf{0 . 3 9}$ & 0.01 & $\mathrm{mg} / \mathrm{g}$ \\
\hline
\end{tabular}


SRNL-STI-2012-00034, Rev. 1

August 3, 2012

Page 25 of 50

Table 11. Radiological Constituents for Tank 5F Composite Sample \#1, $\mu \mathrm{Ci} / \mathrm{g}$.

\begin{tabular}{|c|c|c|c|c|c|c|c|c|}
\hline Analytes & Blank & Run 1, & Run 2 & Run 3 & Average & Stdev. & $\begin{array}{l}\text { One Sigma } \\
\% \text { Uncert. }\end{array}$ & $\begin{array}{c}\text { Targeted } \\
\text { Minimum } \\
\text { Detection } \\
\text { Limits } \\
\end{array}$ \\
\hline Gross alpha & $<4.92 \mathrm{E}+0$ & $<3.23 \mathrm{E}+02$ & $<4.91 \mathrm{E}+02$ & $<4.20 \mathrm{E}+02$ & $<4.12 \mathrm{E}+02$ & & MDA & NA \\
\hline $\begin{array}{c}\text { Non-volatile } \\
\text { beta }\end{array}$ & $<1.09 \mathrm{E}+01$ & $2.95 \mathrm{E}+04$ & $2.98 \mathrm{E}+04$ & $3.05 \mathrm{E}+04$ & $3.00 \mathrm{E}+04$ & $5.19 E+02$ & 10 & NA \\
\hline H-3 & $<9.06 \mathrm{E}-03$ & $<8.65 \mathrm{E}-03$ & $<1.01 \mathrm{E}-02$ & $<9.09 \mathrm{E}-03$ & $<9.28 \mathrm{E}-03$ & & MDA & $1.0 \mathrm{E}-01$ \\
\hline C-14 & $<7.84 \mathrm{E}-04$ & $<8.33 \mathrm{E}-04$ & $<8.51 \mathrm{E}-04$ & $<7.39 \mathrm{E}-04$ & $<8.08 \mathrm{E}-04$ & & MDA & $1.0 \mathrm{E}-01$ \\
\hline Ni-59 & $<9.23 \mathrm{E}-03$ & $4.73 \mathrm{E}+00$ & $7.84 \mathrm{E}+00$ & $6.67 \mathrm{E}+00$ & $6.41 E+00$ & $1.57 E+00$ & 10 & $9.0 \mathrm{E}-02$ \\
\hline Ni-63 & $<8.56 \mathrm{E}-02$ & $2.65 \mathrm{E}+02$ & $3.01 \mathrm{E}+02$ & $3.50 \mathrm{E}+02$ & $3.05 E+02$ & $4.25 E+01$ & 20 & $1.0 \mathrm{E}-01$ \\
\hline Co-60 & $<1.33 \mathrm{E}-02$ & $7.25 \mathrm{E}+00$ & $6.62 \mathrm{E}+00$ & $6.22 \mathrm{E}+00$ & $6.70 \mathrm{E}+00$ & $5.22 E-01$ & 5 & $1.0 \mathrm{E}-03$ \\
\hline Se-79 & No yield & 1.33E-02 & 8.29E-03 & $1.42 \mathrm{E}-02$ & 1.19E-02 & $3.19 E-03$ & 31 & $1.0 \mathrm{E}-03$ \\
\hline Sr-90 & $<7.43 \mathrm{E}+0$ & $1.21 \mathrm{E}+04$ & $1.19 \mathrm{E}+04$ & $1.23 \mathrm{E}+04$ & $1.21 E+04$ & $2.03 E+02$ & 6 & $1.0 \mathrm{E}-03$ \\
\hline Y-90 & $<7.43 \mathrm{E}+0$ & $1.21 \mathrm{E}+04$ & $1.19 \mathrm{E}+04$ & $1.23 \mathrm{E}+04$ & $1.21 \mathrm{E}+04$ & $2.03 E+02$ & 6 & $1.0 \mathrm{E}-03$ \\
\hline Zr-93 & $2.08 \mathrm{E}-02$ & $3.15 \mathrm{E}+00$ & $3.18 \mathrm{E}+00$ & $2.49 \mathrm{E}+00$ & $2.94 \mathrm{E}+00$ & 0.39 & 20 & 1.0E-03 \\
\hline Tc-99 & $<9.86 \mathrm{E}-05$ & $1.02 \mathrm{E}-02$ & $7.66 \mathrm{E}-03$ & 8.47E-03 & 8.78E-03 & $1.31 E-03$ & 6 & $1.0 \mathrm{E}-03$ \\
\hline Pd-107** & $<3.38 \mathrm{E}-04$ & $2.50 \mathrm{E}-03$ & $2.51 \mathrm{E}-03$ & $2.81 \mathrm{E}-03$ & $2.61 E-03$ & $1.76 E-04$ & 20 & $1.0 \mathrm{E}-03$ \\
\hline I-129 & $<2.31 \mathrm{E}-06$ & $1.10 \mathrm{E}-04$ & $1.98 \mathrm{E}-04$ & $1.64 \mathrm{E}-04$ & 1.57E-04 & $4.41 E-05$ & 14 & $1.0 \mathrm{E}-04$ \\
\hline Cs-135 & 8.10E-06 & $2.34 \mathrm{E}-03$ & $1.86 \mathrm{E}-03$ & $1.67 \mathrm{E}-03$ & 1.96E-03 & $3.45 E-04$ & 20 & $5.0 \mathrm{E}-02$ \\
\hline Cs-137 & $<3.23 \mathrm{E}-02$ & $4.47 \mathrm{E}+02$ & $3.71 \mathrm{E}+02$ & $3.49 \mathrm{E}+02$ & $3.89 \mathrm{E}+02$ & $5.14 E+01$ & 5 & $1.0 \mathrm{E}-03$ \\
\hline Ba-137m & $<3.06 \mathrm{E}-02$ & $4.23 \mathrm{E}+02$ & $3.51 \mathrm{E}+02$ & $3.30 \mathrm{E}+02$ & $3.68 E+02$ & $5.14 E+01$ & 5 & $1.0 \mathrm{E}-03$ \\
\hline Pm-147 & $<3.84 \mathrm{E}+00$ & $<4.59 \mathrm{E}+02$ & $<5.45 \mathrm{E}+02$ & $<5.81 \mathrm{E}+02$ & $<6.38 \mathrm{E}+02$ & & & None \\
\hline Sm-151 & $<3.46 \mathrm{E}+0$ & $7.16 \mathrm{E}+02$ & $7.25 \mathrm{E}+02$ & $8.02 \mathrm{E}+02$ & $7.48 \mathrm{E}+02$ & $4.70 E+01$ & 20 & $3.0 \mathrm{E}+00$ \\
\hline Eu-154 & $<2.06 \mathrm{E}-02$ & $3.00 \mathrm{E}+01$ & $2.87 \mathrm{E}+01$ & $2.85 \mathrm{E}+01$ & $2.91 E+01$ & $7.92 E-01$ & 5 & $1.0 \mathrm{E}-03$ \\
\hline Eu-155 & $<4.00 \mathrm{E}-02$ & $3.77 \mathrm{E}+00$ & $5.32 \mathrm{E}+00$ & $4.32 \mathrm{E}+00$ & $4.47 \mathrm{E}+00$ & $7.82 E-01$ & 11 & None \\
\hline Pt-193 & $<8.12 \mathrm{E}-04$ & $<6.37 \mathrm{E}-04$ & $<6.95 \mathrm{E}-04$ & $<4.91 \mathrm{E}-04$ & $<6.08 \mathrm{E}-04$ & & MDA & $1.0 \mathrm{E}-03$ \\
\hline Th-229** & No yield & 2.95E-06 & 4.10E-06 & 2.38E-05 & 1.03E-05 & $1.17 E-05$ & 151 & $1.0 \mathrm{E}-03$ \\
\hline Th-230** & No yield & $1.63 \mathrm{E}-03$ & $1.56 \mathrm{E}-03$ & $2.16 \mathrm{E}-03$ & $1.78 \mathrm{E}-03$ & $3.27 E-04$ & 151 & $1.0 \mathrm{E}-03$ \\
\hline Pa-231** & $<1.44 \mathrm{E}-03$ & $<1.02 \mathrm{E}-03$ & $<2.14 \mathrm{E}-04$ & $<1.41 \mathrm{E}-04$ & $<4.58 \mathrm{E}-04$ & & $\mathrm{DL}$ & $1.0 \mathrm{E}-03$ \\
\hline U-232 & No yield & $<1.82 \mathrm{E}-05$ & $<1.94 \mathrm{E}-05$ & $<1.23 \mathrm{E}-05$ & $<1.66 \mathrm{E}-05$ & & $\mathrm{DL}$ & $1.0 \mathrm{E}-03$ \\
\hline U-233 & $<2.05 \mathrm{E}-03$ & $<2.62 \mathrm{E}-04$ & $<2.64 \mathrm{E}-04$ & $<2.48 \mathrm{E}-04$ & $<2.58 \mathrm{E}-04$ & & $\mathrm{DL}$ & $1.0 \mathrm{E}-03$ \\
\hline U-234 & $<1.32 \mathrm{E}-03$ & 4.27E-03 & $4.08 \mathrm{E}-03$ & $3.54 \mathrm{E}-03$ & 3.96E-03 & $3.79 E-04$ & 20 & $1.0 \mathrm{E}-03$ \\
\hline U-235 & $<4.60 \mathrm{E}-07$ & $1.80 \mathrm{E}-04$ & $1.78 \mathrm{E}-04$ & $1.60 \mathrm{E}-04$ & 1.73E-04 & $1.10 E-05$ & 20 & $1.0 \mathrm{E}-04$ \\
\hline U-236 & $<1.38 \mathrm{E}-05$ & $2.25 \mathrm{E}-04$ & $2.24 \mathrm{E}-04$ & $1.95 \mathrm{E}-04$ & 2.15E-04 & $1.70 E-05$ & 20 & $1.0 \mathrm{E}-03$ \\
\hline U-238 & $8.34 \mathrm{E}-07$ & 4.19E-03 & $4.10 \mathrm{E}-03$ & $3.65 \mathrm{E}-03$ & 3.98E-03 & $2.89 E-04$ & 20 & $1.0 \mathrm{E}-03$ \\
\hline Np-237 & $<1.72 \mathrm{E}-04$ & $2.41 \mathrm{E}-02$ & $2.51 \mathrm{E}-02$ & $1.12 \mathrm{E}-02$ & 2.01E-02 & $7.75 E-03$ & 26 & $1.0 \mathrm{E}-03$ \\
\hline Pu-238 & 6.80E-02 & $2.89 \mathrm{E}+00$ & $2.51 \mathrm{E}+00$ & $2.28 \mathrm{E}+00$ & $2.56 \mathrm{E}+00$ & 3.09E-01 & 7 & $1.0 \mathrm{E}-03$ \\
\hline Pu-239 & $<3.61 \mathrm{E}-02$ & $8.80 \mathrm{E}+00$ & $8.47 \mathrm{E}+00$ & $7.25 \mathrm{E}+00$ & $8.17 E+00$ & $8.16 E-01$ & 20 & $1.0 \mathrm{E}-03$ \\
\hline Pu-240 & $<1.32 \mathrm{E}-01$ & $2.05 \mathrm{E}+00$ & $1.97 \mathrm{E}+00$ & $1.68 \mathrm{E}+00$ & $1.90 \mathrm{E}+00$ & $1.95 E-01$ & 20 & $1.0 \mathrm{E}-03$ \\
\hline Pu-239/240 & $<4.55 \mathrm{E}-02$ & $1.09 \mathrm{E}+01$ & $1.05 E+01$ & $8.92 \mathrm{E}+00$ & $1.01 E+01$ & $1.02 E+00$ & 5 & None \\
\hline
\end{tabular}

** While analyses of these isotopes is needed, meeting the detection limits for these isotopes is a lower priority than meeting detection

limits for the other specified isotopes. 
SRNL-STI-2012-00034, Rev. 1

August 3, 2012

Page 26 of 50

Table 11-continued. Radiological Constituents for Tank 5F Composite Sample \#1 Continued, $\mu \mathrm{Ci} / \mathrm{g}$.

\begin{tabular}{|c|c|c|c|c|c|c|c|c|}
\hline Analytes & Blank & Run 1 & Run 2 & Run 3 & Average & Stdev & $\begin{array}{l}\text { One Sigma } \\
\text { \%Uncert. }\end{array}$ & $\begin{array}{c}\text { Targeted } \\
\text { Minimum } \\
\text { Detection } \\
\text { Limits }\end{array}$ \\
\hline Pu-241 & $<1.05 \mathrm{E}-02$ & $<1.19 \mathrm{E}+01$ & $<1.19 \mathrm{E}+01$ & $<1.30 \mathrm{E}+01$ & $<1.23 \mathrm{E}+01$ & & Upper Limit & $1.0 \mathrm{E}-03$ \\
\hline Pu-242 & $<2.29 \mathrm{E}-03$ & 3.97E-04 & 4.24E-04 & 3.41E-04 & 3.87E-04 & $4.23 E-05$ & 20 & $1.0 \mathrm{E}-03$ \\
\hline Pu-244 & $<1.07 \mathrm{E}-05$ & $<8.36 \mathrm{E}-07$ & $<1.05 \mathrm{E}-06$ & $<9.74 \mathrm{E}-07$ & $<$ <9.53E-07 & & DL & $1.30 \mathrm{E}-04$ \\
\hline Am-241 & $<7.39 \mathrm{E}-02$ & $7.30 \mathrm{E}+01$ & $6.53 \mathrm{E}+01$ & $6.40 \mathrm{E}+01$ & $6.74 \mathrm{E}+01$ & $4.86 E+00$ & 5 & $1.0 \mathrm{E}-03$ \\
\hline Am-242m & $<1.01 \mathrm{E}-03$ & 1.77E-01 & 1.70E-01 & 1.41E-01 & 1.63E-01 & $1.92 E-02$ & 24 & $1.0 \mathrm{E}-03$ \\
\hline Am-243 & $<5.72 \mathrm{E}-04$ & $5.45 \mathrm{E}-01$ & 5.09E-01 & 4.77E-01 & 5.11E-01 & $3.38 E-02$ & 6.5 & $1.0 \mathrm{E}-03$ \\
\hline Cm-242 & $<8.33 \mathrm{E}-04$ & 1.47E-01 & $1.41 \mathrm{E}-01$ & $1.17 \mathrm{E}-01$ & 1.35E-01 & $3.05 E-01$ & 24. & None \\
\hline Cm-243 & $<4.64 \mathrm{E}-04$ & $<7.52 \mathrm{E}-02$ & $<5.77 \mathrm{E}-02$ & $<4.36 \mathrm{E}-01$ & $<1.90 \mathrm{E}-01$ & & Upper limit & $2.0 \mathrm{E}-02$ \\
\hline Cm-244 & $<7.93 \mathrm{E}-03$ & $3.32 \mathrm{E}+00$ & $2.98 \mathrm{E}+00$ & $3.59 \mathrm{E}+00$ & $3.29 \mathrm{E}+00$ & $1.59 E-02$ & 11.4 & $1.0 \mathrm{E}-03$ \\
\hline Cm-245 & $<8.11 \mathrm{E}-06$ & $<1.45 \mathrm{E}-03$ & $<1.35 \mathrm{E}-03$ & $<7.03 \mathrm{E}-04$ & $<1.17 \mathrm{E}-03$ & & Upper limit & $2.0 \mathrm{E}-02$ \\
\hline Cm-246 & $<1.68 \mathrm{E}-05$ & $<2.09 \mathrm{E}-03$ & $<2.39 \mathrm{E}-03$ & $<1.24 \mathrm{E}-03$ & $<1.91 \mathrm{E}-03$ & & Upper limit & $2.0 \mathrm{E}-02$ \\
\hline Cm-247 & $<4.82 \mathrm{E}-09$ & $<4.68 \mathrm{E}-07$ & $<3.67 \mathrm{E}-07$ & $<1.47 \mathrm{E}-07$ & $<3.27 \mathrm{E}-07$ & & Upper limit & $1.3 \mathrm{E}-04$ \\
\hline Bk-247 & $<5.36 \mathrm{E}-05$ & $<5.23 \mathrm{E}-03$ & $<4.09 \mathrm{E}-03$ & $<1.64 \mathrm{E}-03$ & $<3.65 \mathrm{E}-03$ & & Upper limit & None \\
\hline Cm-248 & $<5.90 \mathrm{E}-07$ & $<5.72 \mathrm{E}-05$ & $<3.43 \mathrm{E}-05$ & $<1.45 \mathrm{E}-05$ & $<3.53 \mathrm{E}-05$ & & Upper limit & $1.30 \mathrm{E}-04$ \\
\hline Cf-249 & $<1.05 \mathrm{E}-04$ & $<1.78 \mathrm{E}-02$ & $<1.36 \mathrm{E}-02$ & $<7.39 \mathrm{E}-03$ & $<1.29 \mathrm{E}-02$ & & MDA & $5.0 \mathrm{E}-03$ \\
\hline Cf-250 & $<1.22 \mathrm{E}-05$ & $<8.29 \mathrm{E}-04$ & $<7.61 \mathrm{E}-04$ & $<2.24 \mathrm{E}-04$ & $<6.05 \mathrm{E}-04$ & & Upper limit & None \\
\hline Cf-251 & $<2.28 \mathrm{E}-04$ & $<4.82 \mathrm{E}-02$ & $<3.66 \mathrm{E}-02$ & $<1.99 \mathrm{E}-02$ & $<3.49 \mathrm{E}-02$ & & MDA & None \\
\hline Cf-252 & $<8.33 \mathrm{E}-04$ & $<1.47 \mathrm{E}-01$ & $<1.41 \mathrm{E}-01$ & $<1.17 \mathrm{E}-01$ & $<1.35 \mathrm{E}-01$ & & Upper limit & None \\
\hline
\end{tabular}


SRNL-STI-2012-00034, Rev. 1

August 3, 2012

Page 27 of 50

Table 12. Radiological Constituents for Tank 5F Composite Sample \#2, $\mu \mathrm{Ci} / \mathrm{g}$.

\begin{tabular}{|c|c|c|c|c|c|c|c|c|}
\hline Analytes & Blank & Run 1 & Run 2 & Run 3 & Average & Stdev & $\begin{array}{c}\text { One Sigma } \\
\text { \%Uncert. }\end{array}$ & $\begin{array}{c}\text { Targeted } \\
\text { Minimum } \\
\text { Detection } \\
\text { Limits }\end{array}$ \\
\hline Gross alpha & $<2.34 \mathrm{E}+01$ & $<3.09 \mathrm{E}+02$ & $<3.48 \mathrm{E}+02$ & $<1.07 \mathrm{E}+03$ & $<5.77 \mathrm{E}+02$ & & MDA & None \\
\hline $\begin{array}{c}\text { Non-volatile } \\
\text { beta }\end{array}$ & $<4.40 \mathrm{E}+01$ & $3.24 \mathrm{E}+04$ & $2.98 \mathrm{E}+04$ & $3.12 \mathrm{E}+04$ & $3.12 E+04$ & $1.31 E+03$ & 10 & None \\
\hline H-3 & $<9.06 \mathrm{E}-03$ & $<1.00 \mathrm{E}-02$ & $<8.37 \mathrm{E}-03$ & $<1.72 \mathrm{E}-02$ & $<1.19 E-02$ & & Upper limit & $1.0 \mathrm{E}-01$ \\
\hline C-14 & $<7.84 \mathrm{E}-04$ & $<7.39 \mathrm{E}-04$ & $<1.58 \mathrm{E}-03$ & $<1.58 \mathrm{E}-03$ & $<1.30 \mathrm{E}-03$ & & MDA & $1.0 \mathrm{E}-01$ \\
\hline Ni-59 & $<9.23 \mathrm{E}-03$ & $5.18 \mathrm{E}+00$ & $5.72 \mathrm{E}+00$ & $4.50 \mathrm{E}+00$ & $5.14 \mathrm{E}+00$ & $6.09 E-01$ & 10 & $9.0 \mathrm{E}-02$ \\
\hline Ni-63 & $<8.56 \mathrm{E}-02$ & $2.18 \mathrm{E}+02$ & $2.33 \mathrm{E}+02$ & $2.10 \mathrm{E}+02$ & $2.20 \mathrm{E}+02$ & $1.19 E+01$ & 20 & $1.0 \mathrm{E}-01$ \\
\hline Co-60 & $<1.33 \mathrm{E}-02$ & $6.85 \mathrm{E}+00$ & $6.04 \mathrm{E}+00$ & $6.94 \mathrm{E}+00$ & $6.61 \mathrm{E}+00$ & $4.96 E-01$ & 5 & None \\
\hline Se-79 & No yield & $5.86 \mathrm{E}-03$ & 3.17E-03 & $1.85 \mathrm{E}-02$ & 9.17E-03 & $8.17 E-03$ & 49 & $1.0 \mathrm{E}-03$ \\
\hline Sr-90 & $<7.43 \mathrm{E}+0$ & $1.28 \mathrm{E}+04$ & $1.25 \mathrm{E}+04$ & $1.23 \mathrm{E}+04$ & $1.26 \mathrm{E}+04$ & $2.72 E+02$ & 6 & $1.0 \mathrm{E}-03$ \\
\hline Y-90 & $<7.43 \mathrm{E}+0$ & $1.28 \mathrm{E}+04$ & $1.25 \mathrm{E}+04$ & $1.23 \mathrm{E}+04$ & $1.26 \mathrm{E}+04$ & $2.72 E+02$ & 6 & $1.0 \mathrm{E}-03$ \\
\hline Zr-93 & $2.08 \mathrm{E}-02$ & $3.12 \mathrm{E}+00$ & $2.70 \mathrm{E}+00$ & $2.83 \mathrm{E}+00$ & $2.88 \mathrm{E}+00$ & 0.22 & 20 & $1.0 \mathrm{E}-03$ \\
\hline Tc-99 & $<9.86 \mathrm{E}-05$ & $1.06 \mathrm{E}-02$ & 9.64E-03 & $1.26 \mathrm{E}-02$ & 1.09E-02 & $1.49 E-03$ & 6.7 & $1.0 \mathrm{E}-03$ \\
\hline Pd-107** & $<3.38 \mathrm{E}-04$ & 6.12E-03 & $2.21 \mathrm{E}-03$ & 8.04E-03 & $5.46 \mathrm{E}-03$ & $2.97 E-03$ & 20 & $1.0 \mathrm{E}-03$ \\
\hline I-129 & $<2.31 \mathrm{E}-06$ & $1.36 \mathrm{E}-04$ & $<3.49 \mathrm{E}-03$ & 1.18E-03 & $\leq 1.60 \mathrm{E}-03$ & & 8.0/MDA & $1.0 \mathrm{E}-04$ \\
\hline Cs-135 & 8.10E-06 & $2.58 \mathrm{E}-03$ & $1.70 \mathrm{E}-03$ & $2.23 E-03$ & 2.17E-03 & $4.43 E-04$ & 20 & $5.0 \mathrm{E}-02$ \\
\hline Cs-137 & $<3.23 E-02$ & $4.55 \mathrm{E}+02$ & $3.53 \mathrm{E}+02$ & $4.35 \mathrm{E}+02$ & $4.14 \mathrm{E}+02$ & $5.42 E+01$ & 5 & $1.0 \mathrm{E}-03$ \\
\hline Ba-137m & $<3.06 \mathrm{E}-02$ & $4.30 \mathrm{E}+02$ & $3.34 \mathrm{E}+02$ & $4.12 \mathrm{E}+02$ & $3.92 \mathrm{E}+02$ & $5.42 E+01$ & 5 & $1.0 \mathrm{E}-03$ \\
\hline Pm-147 & $<3.84 \mathrm{E}+00$ & $<5.95 \mathrm{E}+02$ & $<5.36 \mathrm{E}+02$ & $<5.63 \mathrm{E}+02$ & $<6.58 \mathrm{E}+02$ & & & None \\
\hline Sm-151 & $<3.46 \mathrm{E}+0$ & $7.88 \mathrm{E}+02$ & $7.07 \mathrm{E}+02$ & $7.57 \mathrm{E}+02$ & $7.51 \mathrm{E}+02$ & $4.09 E+01$ & 20 & $3.0 \mathrm{E}+00$ \\
\hline Eu-154 & $<2.06 \mathrm{E}-02$ & $2.98 \mathrm{E}+01$ & $2.73 \mathrm{E}+01$ & $2.93 \mathrm{E}+01$ & $2.88 \mathrm{E}+01$ & $1.35 E+00$ & 5 & $1.0 \mathrm{E}-03$ \\
\hline Eu-155 & $<4.00 \mathrm{E}-02$ & $3.79 \mathrm{E}+00$ & $4.36 \mathrm{E}+00$ & $4.33 E+00$ & $4.16 \mathrm{E}+00$ & $3.18 E-01$ & 13 & None \\
\hline Th-229** & No yield & $3.77 \mathrm{E}-06$ & 6.67E-06 & $8.11 \mathrm{E}-06$ & 6.18E-06 & $2.21 E-06$ & 202 & $1.0 \mathrm{E}-03$ \\
\hline Th-230** & No yield & 5.99E-04 & $2.31 \mathrm{E}-03$ & 3.50E-04 & 1.09E-03 & $1.06 E-03$ & 202 & $1.0 \mathrm{E}-03$ \\
\hline Рa-231** & $<1.44 \mathrm{E}-03$ & $<2.35 \mathrm{E}-04$ & $<2.77 \mathrm{E}-04$ & $<2.53 \mathrm{E}-04$ & $<2.55 E-04$ & & DL & $1.0 \mathrm{E}-03$ \\
\hline U-232 & No yield & $<1.59 \mathrm{E}-05$ & $<2.72 \mathrm{E}-05$ & $<3.47 \mathrm{E}-05$ & $<2.59 E-05$ & & DL & $1.0 \mathrm{E}-03$ \\
\hline U-233 & $<2.05 \mathrm{E}-03$ & $<2.52 \mathrm{E}-04$ & $<2.56 \mathrm{E}-04$ & $<7.58 \mathrm{E}-03$ & $<2.70 \mathrm{E}-03$ & & $\mathrm{DL}$ & $1.0 \mathrm{E}-03$ \\
\hline U-234 & $<1.32 \mathrm{E}-03$ & 5.33E-03 & $4.32 \mathrm{E}-03$ & $<4.89 \mathrm{E}-03$ & $\leq 4.85 \mathrm{E}-03$ & & 20/MDA & $1.0 \mathrm{E}-03$ \\
\hline U-235 & $<4.60 \mathrm{E}-07$ & 2.33E-04 & $1.87 \mathrm{E}-04$ & $2.25 \mathrm{E}-04$ & 2.15E-04 & $2.46 E-05$ & 20 & $1.0 \mathrm{E}-04$ \\
\hline U-236 & $<1.38 \mathrm{E}-05$ & $2.85 \mathrm{E}-04$ & $2.29 \mathrm{E}-04$ & $2.70 \mathrm{E}-04$ & 2.61E-04 & $2.90 E-05$ & 20 & $1.0 \mathrm{E}-03$ \\
\hline U-238 & 8.34E-07 & 5.33E-03 & 4.31E-03 & 5.29E-03 & 4.98E-03 & $5.78 E-04$ & 20 & $1.0 \mathrm{E}-03$ \\
\hline Np-237 & $<1.72 \mathrm{E}-04$ & 1.19E-02 & $2.66 \mathrm{E}-02$ & 3.22E-02 & 2.36E-02 & $1.05 E-02$ & 27.7 & $1.0 \mathrm{E}-03$ \\
\hline Pu-238 & 6.80E-02 & $2.40 \mathrm{E}+00$ & $2.24 \mathrm{E}+00$ & $2.58 \mathrm{E}+00$ & $2.41 \mathrm{E}+00$ & $1.71 E-01$ & 7.8 & $1.0 \mathrm{E}-03$ \\
\hline Pu-239 & $<1.32 \mathrm{E}-01$ & $8.12 \mathrm{E}+00$ & $6.21 \mathrm{E}+00$ & $8.83 \mathrm{E}+00$ & $7.72 \mathrm{E}+00$ & $1.36 E+00$ & 20 & $1.0 \mathrm{E}-03$ \\
\hline Pu-240 & $<4.55 \mathrm{E}-02$ & $1.88 \mathrm{E}+00$ & $1.47 \mathrm{E}+00$ & $2.08 \mathrm{E}+00$ & $1.81 \mathrm{E}+00$ & $3.11 E-01$ & 20 & $1.0 \mathrm{E}-03$ \\
\hline Pu-239/240 & 4.55E-02 & $1.00 \mathrm{E}+01$ & $7.66 \mathrm{E}+00$ & $1.09 \mathrm{E}+01$ & $9.52 \mathrm{E}+00$ & $1.67 E+00$ & 5 & None \\
\hline
\end{tabular}

** While analyses of these isotopes is needed, meeting the detection limits for these isotopes is a lower priority than meeting detection limits for the other specified isotopes. . 
SRNL-STI-2012-00034, Rev. 1

August 3, 2012

Page 28 of 50

Table 12-continued. Radiological Constituents for Tank 5F Composite Sample \#2, $\mu \mathrm{Ci} / \mathrm{g}$.

\begin{tabular}{|c|c|c|c|c|c|c|c|c|}
\hline Analytes & Blank & Run 1 & Run 2 & Run 3 & Average & Stdev & $\begin{array}{l}\text { One Sigma } \\
\text { \%Uncertainty }\end{array}$ & $\begin{array}{c}\text { Targeted } \\
\text { Minimum } \\
\text { Detection } \\
\text { Limits }\end{array}$ \\
\hline Pu-241 & $\begin{array}{c}<4.33 \mathrm{E}-02 \\
\end{array}$ & $<1.37 \mathrm{E}+01$ & $<8.51 \mathrm{E}+00$ & $<8.69 \mathrm{E}+0$ & $<1.03 \mathrm{E}+01$ & & Upper Limit & $1.0 \mathrm{E}-03$ \\
\hline Pu-242 & $<2.29 \mathrm{E}-03$ & 3.32E-04 & 2.70E-04 & 3.95E-04 & 3.32E-04 & $6.25 E-05$ & 20 & $1.0 \mathrm{E}-03$ \\
\hline Pu-244 & $<1.07 \mathrm{E}-05$ & $<1.17 \mathrm{E}-06$ & $<7.43 \mathrm{E}-07$ & $<9.46 \mathrm{E}-07$ & $<9.53 \mathrm{E}-07$ & & DL & 1.30E-04 \\
\hline Am-241 & $\begin{array}{c}<7.39 \mathrm{E}-02 \\
\end{array}$ & $7.12 \mathrm{E}+01$ & $6.35 \mathrm{E}+01$ & $7.16 \mathrm{E}+01$ & $6.88 \mathrm{E}+01$ & $4.56 E+00$ & 5 & $1.0 \mathrm{E}-03$ \\
\hline Am-242m & $<1.01 \mathrm{E}-03$ & $1.90 \mathrm{E}-01$ & $1.27 \mathrm{E}-01$ & 1.73E-01 & 1.63E-01 & $3.27 E-02$ & 20 & $1.0 \mathrm{E}-03$ \\
\hline Am-243 & $<5.72 \mathrm{E}-04$ & $5.54 \mathrm{E}-01$ & 4.77E-01 & 5.72E-01 & 5.35E-01 & $5.02 E-02$ & 6 & $1.0 \mathrm{E}-03$ \\
\hline Cm-242 & $<8.33 \mathrm{E}-04$ & $1.57 \mathrm{E}-01$ & 1.05E-01 & $1.43 \mathrm{E}-01$ & 1.35E-01 & $2.71 E-02$ & 20.02 & None \\
\hline Cm-243 & $<4.64 \mathrm{E}-04$ & $<5.36 \mathrm{E}-01$ & $<4.64 \mathrm{E}-01$ & $<3.31 \mathrm{E}-01$ & $<4.44 \mathrm{E}-01$ & & Upper Limit & $2.0 \mathrm{E}-02$ \\
\hline Cm-244 & $<7.93 \mathrm{E}-03$ & $2.93 \mathrm{E}+00$ & $2.57 \mathrm{E}+00$ & $2.88 \mathrm{E}+00$ & $2.79 \mathrm{E}+00$ & $1.98 E-01$ & 10.9 & $1.0 \mathrm{E}-03$ \\
\hline Cm-245 & $<8.11 \mathrm{E}-06$ & $<7.70 \mathrm{E}-04$ & $<6.22 \mathrm{E}-04$ & $<5.63 \mathrm{E}-04$ & $<6.52 \mathrm{E}-04$ & & Upper Limit & $2.0 \mathrm{E}-02$ \\
\hline Cm-246 & $<1.68 \mathrm{E}-05$ & $<1.98 \mathrm{E}-03$ & $<1.04 \mathrm{E}-03$ & $<1.11 \mathrm{E}-03$ & $<1.38 \mathrm{E}-03$ & & Upper Limit & None \\
\hline Cm-247 & $<4.82 \mathrm{E}-09$ & $<2.81 \mathrm{E}-07$ & $<1.74 \mathrm{E}-07$ & $<1.03 \mathrm{E}-07$ & $<1.86 \mathrm{E}-07$ & & Upper Limit & $1.3 \mathrm{E}-04$ \\
\hline Bk-247 & $<<5.36 \mathrm{E}-05$ & $<3.13 \mathrm{E}-03$ & $<1.94 \mathrm{E}-03$ & $<1.15 \mathrm{E}-03$ & $<2.07 E-03$ & & Upper Limit & None \\
\hline Cm-248 & $<5.90 \mathrm{E}-07$ & $<3.96 \mathrm{E}-05$ & $<1.93 \mathrm{E}-05$ & $<1.32 \mathrm{E}-05$ & $<2.40 \mathrm{E}-05$ & & Upper Limit & 1.30E-04 \\
\hline Cf-249 & $<1.05 \mathrm{E}-04$ & $<1.19 \mathrm{E}-02$ & $<1.13 \mathrm{E}-02$ & $<7.75 \mathrm{E}-03$ & $<1.03 \mathrm{E}-02$ & & MDA & $5.0 \mathrm{E}-03$ \\
\hline Cf-250 & $<1.22 \mathrm{E}-05$ & $<3.46 \mathrm{E}-04$ & $<3.68 \mathrm{E}-04$ & $<1.52 \mathrm{E}-04$ & $<2.89 \mathrm{E}-04$ & & Upper Limit & None \\
\hline Cf-251 & $<2.28 \mathrm{E}-04$ & $<3.18 \mathrm{E}-02$ & $<3.00 \mathrm{E}-02$ & $<1.65 \mathrm{E}-02$ & $<2.61 \mathrm{E}-02$ & & MDA & None \\
\hline Cf-252 & $<8.33 \mathrm{E}-04$ & $<1.57 \mathrm{E}-01$ & $<1.05 \mathrm{E}-01$ & $<1.43 \mathrm{E}-01$ & $<1.35 \mathrm{E}-01$ & & Upper Limit & None \\
\hline
\end{tabular}


SRNL-STI-2012-00034, Rev. 1

August 3, 2012

Page 29 of 50

Table 13. Radiological Constituents for Tank 5F Composite Sample \#3, $\mu \mathrm{Ci} / \mathrm{g}$.

\begin{tabular}{|c|c|c|c|c|c|c|c|c|}
\hline Analytes & Blank & Run 1 & Run 2 & Run 3 & Average & Stdev & $\begin{array}{l}\text { One Sigma } \\
\% \text { Uncert. }\end{array}$ & $\begin{array}{c}\text { Targeted } \\
\text { Minimum } \\
\text { Detection } \\
\text { Limits }\end{array}$ \\
\hline Gross alpha & $<2.34 \mathrm{E}+01$ & $<2.09 \mathrm{E}+02$ & $<6.58 \mathrm{E}+02$ & $<3.68 \mathrm{E}+02$ & $<4.11 \mathrm{E}+02$ & & MDA & None \\
\hline $\begin{array}{c}\text { Non-volatile } \\
\text { beta }\end{array}$ & $<4.40 \mathrm{E}+01$ & $2.85 \mathrm{E}+04$ & $2.78 \mathrm{E}+04$ & $2.76 \mathrm{E}+04$ & $2.80 \mathrm{E}+04$ & $4.62 E+02$ & 10 & None \\
\hline H-3 & $<9.06 \mathrm{E}-03$ & $<9.28 \mathrm{E}-03$ & $<9.53 \mathrm{E}-03$ & $<1.83 \mathrm{E}-02$ & $<1.24 \mathrm{E}-02$ & & Upper limit & $1.0 \mathrm{E}-01$ \\
\hline C-14 & $<7.84 \mathrm{E}-04$ & $<3.30 \mathrm{E}-03$ & $<3.40 \mathrm{E}-03$ & $<7.52 \mathrm{E}-04$ & $<2.48 \mathrm{E}-03$ & & MDA & $1.0 \mathrm{E}-01$ \\
\hline Ni-59 & $<9.23 \mathrm{E}-03$ & $5.14 \mathrm{E}+00$ & $3.82 \mathrm{E}+00$ & $6.04 \mathrm{E}+00$ & $5.00 \mathrm{E}+00$ & $1.11 E+00$ & 10 & $9.0 \mathrm{E}-02$ \\
\hline Ni-63 & $<8.56 \mathrm{E}-02$ & $3.34 \mathrm{E}+02$ & $4.64 \mathrm{E}+02$ & $2.98 \mathrm{E}+02$ & $3.65 E+02$ & $8.73 E+01$ & 20 & $1.0 \mathrm{E}-01$ \\
\hline Co-60 & $<1.33 \mathrm{E}-02$ & $7.16 \mathrm{E}+00$ & $7.30 \mathrm{E}+00$ & $6.89 \mathrm{E}+00$ & $7.12 \mathrm{E}+00$ & $2.06 E-01$ & 5 & None \\
\hline Se-79 & No yield & 5.05E-03 & $1.18 \mathrm{E}-02$ & $1.18 \mathrm{E}-02$ & $9.56 \mathrm{E}-03$ & $3.91 E-03$ & 20 & 1.0E-03 \\
\hline Sr-90 & $<7.43 \mathrm{E}+0$ & $1.17 \mathrm{E}+04$ & $1.03 \mathrm{E}+04$ & $1.25 \mathrm{E}+04$ & $1.15 E+04$ & $1.12 E+03$ & 6 & $1.0 \mathrm{E}-03$ \\
\hline Y-90 & $<7.43 \mathrm{E}+0$ & $1.17 \mathrm{E}+04$ & $1.03 \mathrm{E}+04$ & $1.25 \mathrm{E}+04$ & $1.15 E+04$ & $1.12 E+03$ & 6 & $1.0 \mathrm{E}-03$ \\
\hline Zr-93 & $2.08 \mathrm{E}-02$ & $3.07 E+00$ & $3.08 \mathrm{E}+00$ & $3.25 \mathrm{E}+00$ & $3.13 E+00$ & 0.10 & 20 & 1.0E-03 \\
\hline Tc-99 & $<9.86 \mathrm{E}-05$ & $1.07 \mathrm{E}-02$ & $9.10 \mathrm{E}-03$ & $1.11 \mathrm{E}-02$ & 1.03E-02 & $1.05 E-03$ & 6.4 & $1.0 \mathrm{E}-03$ \\
\hline Pd-107** & $<3.38 \mathrm{E}-04$ & $3.46 \mathrm{E}-03$ & $2.62 \mathrm{E}-03$ & $3.55 \mathrm{E}-03$ & $3.21 E-03$ & $5.13 E-04$ & 20 & $1.0 \mathrm{E}-03$ \\
\hline I-129 & $<2.31 \mathrm{E}-06$ & $2.50 \mathrm{E}-04$ & 2.95E-04 & $1.38 \mathrm{E}-04$ & $2.28 \mathrm{E}-04$ & $8.08 E-05$ & 15 & $1.0 \mathrm{E}-04$ \\
\hline Cs-135 & 8.10E-06 & $2.13 \mathrm{E}-03$ & $2.44 \mathrm{E}-03$ & 2.09E-03 & $2.22 \mathrm{E}-03$ & $1.92 E-04$ & 20 & $5.0 \mathrm{E}-02$ \\
\hline Cs-137 & $<3.23 E-02$ & $4.59 \mathrm{E}+02$ & $4.77 \mathrm{E}+02$ & $3.85 \mathrm{E}+02$ & $4.41 \mathrm{E}+02$ & $4.92 E+01$ & 5 & $1.0 \mathrm{E}-03$ \\
\hline Вa-137m & $<3.06 \mathrm{E}-02$ & $4.34 \mathrm{E}+02$ & $4.51 \mathrm{E}+02$ & $3.64 \mathrm{E}+02$ & $4.17 \mathrm{E}+02$ & $4.92 E+01$ & 5 & 1.0E-03 \\
\hline Pm-147 & $<3.84 \mathrm{E}+00$ & $<6.40 \mathrm{E}+02$ & $<6.08 \mathrm{E}+02$ & $<6.22 \mathrm{E}+02$ & $<7.31 \mathrm{E}+02$ & & & None \\
\hline Sm-151 & $<3.46 \mathrm{E}+0$ & $8.51 \mathrm{E}+02$ & $8.38 \mathrm{E}+02$ & $8.29 \mathrm{E}+02$ & 8.39E+02 & $1.13 E+01$ & 19.7 & $3.0 \mathrm{E}+00$ \\
\hline Eu-154 & $<2.06 \mathrm{E}-02$ & $3.15 \mathrm{E}+01$ & $3.14 \mathrm{E}+01$ & $3.22 \mathrm{E}+01$ & $3.17 \mathrm{E}+01$ & $4.19 E-01$ & 5.0 & $1.0 \mathrm{E}-03$ \\
\hline Eu-155 & $<4.00 \mathrm{E}-02$ & $7.12 \mathrm{E}+00$ & $6.71 \mathrm{E}+00$ & $5.95 \mathrm{E}+00$ & $6.59 \mathrm{E}+00$ & $5.95 E-01$ & 7.6 & NA \\
\hline Th-229** & No yield & $<1.05 \mathrm{E}-06$ & $1.22 \mathrm{E}-06$ & 4.23E-05 & $\leq 1.49 \mathrm{E}-05$ & & MDA/101 & $1.0 \mathrm{E}-03$ \\
\hline Th-230** & No yield & $5.72 \mathrm{E}-04$ & 9.19E-04 & $3.88 \mathrm{E}-03$ & 1.79E-03 & $1.82 E-03$ & 82.9 & $1.0 \mathrm{E}-03$ \\
\hline Рa-231** & $<1.44 \mathrm{E}-03$ & NA & $<3.01 \mathrm{E}-04$ & $<3.89 \mathrm{E}-04$ & $<3.45 \mathrm{E}-04$ & & DL & $1.0 \mathrm{E}-03$ \\
\hline U-232 & No yield & $<5.63 \mathrm{E}-06$ & $<4.62 \mathrm{E}-06$ & $<2.23 \mathrm{E}-05$ & $<1.09 \mathrm{E}-05$ & & DL & $1.0 \mathrm{E}-03$ \\
\hline U-233 & $<2.05 \mathrm{E}-03$ & $<2.49 \mathrm{E}-04$ & $<2.34 \mathrm{E}-04$ & $<2.65 E-04$ & $<2.49 \mathrm{E}-04$ & & DL & $1.0 \mathrm{E}-03$ \\
\hline U-234 & $<1.32 \mathrm{E}-03$ & 4.67E-03 & 4.69E-03 & 4.30E-03 & $4.55 \mathrm{E}-03$ & $2.20 E-04$ & 20 & $1.0 \mathrm{E}-03$ \\
\hline U-235 & $<4.60 \mathrm{E}-07$ & $2.09 \mathrm{E}-04$ & $2.08 \mathrm{E}-04$ & $1.96 \mathrm{E}-04$ & 2.04E-04 & $7.23 E-06$ & 20 & $1.0 \mathrm{E}-04$ \\
\hline U-236 & $<1.38 \mathrm{E}-05$ & 2.59E-04 & 2.55E-04 & $2.36 \mathrm{E}-04$ & 2.50E-04 & $1.23 E-05$ & 20 & $1.0 \mathrm{E}-03$ \\
\hline U-238 & 8.34E-07 & $4.86 \mathrm{E}-03$ & $4.82 \mathrm{E}-03$ & $4.50 \mathrm{E}-03$ & 4.73E-03 & $1.97 E-04$ & 20 & $1.0 \mathrm{E}-03$ \\
\hline Np-237 & $<1.72 \mathrm{E}-04$ & $2.78 \mathrm{E}-02$ & $2.54 \mathrm{E}-02$ & $2.34 \mathrm{E}-02$ & $2.55 E-02$ & $2.20 E-03$ & 27.7 & $1.0 \mathrm{E}-03$ \\
\hline Pu-238 & 6.80E-02 & $2.68 \mathrm{E}+00$ & $3.07 \mathrm{E}+00$ & $2.63 \mathrm{E}+00$ & $2.79 \mathrm{E}+00$ & $2.44 E-01$ & 7.6 & 1.0E-03 \\
\hline Pu-239 & 3.61E-02 & $8.80 \mathrm{E}+00$ & $9.11 \mathrm{E}+00$ & $8.42 \mathrm{E}+00$ & $8.78 \mathrm{E}+00$ & $3.46 E-01$ & 20 & 1.0E-03 \\
\hline Pu-240 & $<1.05 E-02$ & $2.06 \mathrm{E}+00$ & $2.14 \mathrm{E}+00$ & $1.97 \mathrm{E}+00$ & $2.06 \mathrm{E}+00$ & $8.50 E-02$ & 20 & $1.0 \mathrm{E}-03$ \\
\hline Pu-239/240 & 4.55E-02 & $1.09 \mathrm{E}+01$ & $1.13 \mathrm{E}+01$ & $1.04 \mathrm{E}+01$ & $1.08 \mathrm{E}+01$ & $4.28 E-01$ & 5.7 & NA \\
\hline
\end{tabular}


SRNL-STI-2012-00034, Rev. 1

August 3, 2012

Page 30 of 50

Table 13-continued. Radiological Constituents for Tank 5F- Composite Sample \#3, $\mu \mathrm{Ci} / \mathrm{g}$.

\begin{tabular}{|c|c|c|c|c|c|c|c|c|}
\hline Analytes & Blank & Run 1 & Run 2 & Run 3 & Average & Stdev. & $\begin{array}{l}\text { One Sigma } \\
\text { \%Uncert. }\end{array}$ & $\begin{array}{c}\text { Targeted } \\
\text { Minimum } \\
\text { Detection Limits }\end{array}$ \\
\hline Pu-241 & $<1.05 \mathrm{E}-02$ & $<1.27 \mathrm{E}+01$ & $<1.28 \mathrm{E}+01$ & $<9.82 \mathrm{E}+00$ & $<1.18 \mathrm{E}+01$ & & Upper Limit & $1.0 \mathrm{E}-03$ \\
\hline Pu-242 & $<2.29 \mathrm{E}-03$ & $4.28 \mathrm{E}-04$ & $4.21 \mathrm{E}-04$ & 3.83E-04 & 4.11E-04 & $2.42 E-05$ & 20 & $1.0 \mathrm{E}-03$ \\
\hline Pu-244 & $<<1.07 \mathrm{E}-05$ & $<8.40 \mathrm{E}-07$ & $<1.12 \mathrm{E}-06$ & $<1.18 \mathrm{E}-06$ & $\begin{array}{l}<1.05 E-06 \\
\end{array}$ & & $\mathrm{DL}$ & 1.30E-04 \\
\hline Am-241 & $\begin{array}{c}<7.39 \mathrm{E}-02 \\
\end{array}$ & $7.34 \mathrm{E}+01$ & $7.70 \mathrm{E}+01$ & $7.12 \mathrm{E}+01$ & $7.39 \mathrm{E}+01$ & $2.95 E+00$ & 5 & $1.0 \mathrm{E}-03$ \\
\hline Am-242m & $<1.01 \mathrm{E}-03$ & 1.90E-01 & $1.42 \mathrm{E}-01$ & NA & 1.66E-01 & $3.38 E-02$ & 22 & $1.0 \mathrm{E}-03$ \\
\hline Am-243 & $<5.72 \mathrm{E}-04$ & 5.54E-01 & 5.63E-01 & NA & 5.59E-01 & $6.37 E-03$ & 6.3 & $1.0 \mathrm{E}-03$ \\
\hline Cm-242 & $\begin{array}{c}<8.33 \mathrm{E}-04 \\
\end{array}$ & $1.57 \mathrm{E}-01$ & $1.18 \mathrm{E}-01$ & NA & 1.37E-01 & $2.77 E-02$ & 25.5 & None \\
\hline Cm-243 & $<4.64 \mathrm{E}-04$ & $<5.68 \mathrm{E}-01$ & $<5.00 \mathrm{E}-01$ & $<1.40 \mathrm{E}+00$ & $<5.34 \mathrm{E}-01$ & & Upper Limit & $2.0 \mathrm{E}-02$ \\
\hline Cm-244 & $\begin{array}{c}<7.93 \mathrm{E}-03 \\
\end{array}$ & $2.99 \mathrm{E}+00$ & $3.04 \mathrm{E}+00$ & NA & $3.01 E+00$ & $3.50 E-02$ & 12.2 & $1.0 \mathrm{E}-03$ \\
\hline Cm-245 & $<<8.11 \mathrm{E}-06$ & $<1.50 \mathrm{E}-03$ & $<7.34 \mathrm{E}-04$ & NA & $<1.11 \mathrm{E}-03$ & & Upper Limit & $2.0 \mathrm{E}-02$ \\
\hline Cm-246 & $<1.68 \mathrm{E}-05$ & $<3.22 \mathrm{E}-03$ & $<1.24 \mathrm{E}-03$ & NA & $<2.23 \mathrm{E}-03$ & & Upper Limit & None \\
\hline Cm-247 & $<4.82 \mathrm{E}-09$ & $<5.41 \mathrm{E}-07$ & $<1.01 \mathrm{E}-07$ & NA & $<3.21 \mathrm{E}-07$ & & Upper Limit & $1.3 \mathrm{E}-04$ \\
\hline Bk-247 & $\begin{array}{c}<5.36 \mathrm{E}-05 \\
\end{array}$ & $<5.99 \mathrm{E}-03$ & $\begin{array}{c}<1.13 \mathrm{E}-03 \\
\end{array}$ & NA & $<3.56 \mathrm{E}-03$ & & Upper Limit & None \\
\hline Cm-248 & $<5.90 \mathrm{E}-07$ & $<5.36 \mathrm{E}-05$ & $<1.39 \mathrm{E}-05$ & NA & $<3.38 \mathrm{E}-05$ & & Upper Limit & 1.30E-04 \\
\hline Cf-249 & $\begin{array}{c}<1.05 \mathrm{E}-04 \\
\end{array}$ & $<1.88 \mathrm{E}-02$ & $<7.93 \mathrm{E}-03$ & NA & $1.34 \mathrm{E}-02$ & & MDA & $5.0 \mathrm{E}-03$ \\
\hline Cf-250 & $<1.22 \mathrm{E}-05$ & $<1.02 \mathrm{E}-03$ & $<2.23 \mathrm{E}-04$ & NA & $6.23 \mathrm{E}-04$ & & Upper Limit & None \\
\hline Cf-251 & $<2.28 \mathrm{E}-04$ & $<5.05 \mathrm{E}-02$ & $<2.11 \mathrm{E}-02$ & NA & $3.58 \mathrm{E}-02$ & & MDA & None \\
\hline Cf-252 & $<8.33 \mathrm{E}-04$ & $<1.57 \mathrm{E}-01$ & $<1.18 \mathrm{E}-01$ & NA & 1.37E-01 & & Upper Limit & None \\
\hline
\end{tabular}


Table 14. Tank 5F Composite Sample \#1: Challenging Radiological Constituents, $\mu \mathrm{Ci} / \mathrm{g}$.

\begin{tabular}{|c|c|c|c|c|}
\hline Analytes & Blank & $\begin{array}{c}\text { Tank 5F } \\
\text { Composite \#1 }\end{array}$ & $\begin{array}{c}\text { One Sigma } \\
\text { \%Uncertainty }\end{array}$ & $\begin{array}{c}\text { Targeted Minimum } \\
\text { Detection Limits }\end{array}$ \\
\hline Al-26 & $<9.77 \mathrm{E}-03$ & $<1.29 \mathrm{E}-02$ & MDA & $1.0 \mathrm{E}-03$ \\
\hline $\mathbf{C l - 3 6}$ & $<2.43 \mathrm{E}-02$ & $<2.87 \mathrm{E}-03$ & Upper limit & $1.0 \mathrm{E}-03$ \\
\hline K-40 & $<5.54 \mathrm{E}-04$ & $<5.14 \mathrm{E}-03$ & MDA & $1.0 \mathrm{E}-03$ \\
\hline Nb-94 & $<5.33 \mathrm{E}-03$ & $<2.87 \mathrm{E}-03$ & MDA & $3.0 \mathrm{E}-03$ \\
\hline Sn-126 & $<3.57 \mathrm{E}-02$ & $<8.06 \mathrm{E}-01$ & MDA & $1.0 \mathrm{E}-03$ \\
\hline Sb-126 & $<1.14 \mathrm{E}-02$ & $<1.09 \mathrm{E}-01$ & MDA & $1.0 \mathrm{E}-03$ \\
\hline Sb-126m & $<1.14 \mathrm{E}-02$ & $<1.09 \mathrm{E}-01$ & MDA & $7.0 \mathrm{E}-03$ \\
\hline Eu-152 & $<2.95 \mathrm{E}-02$ & $<2.11 \mathrm{E}-01$ & MDA & $1.0 \mathrm{E}-03$ \\
\hline Pt-193 & $<8.12 \mathrm{E}-04$ & $<4.91 \mathrm{E}-04$ & MDA & $5.0 \mathrm{E}-03$ \\
\hline Ra-226** & No yield & $<9.78 \mathrm{E}-03$ & MDA & $1.30 \mathrm{E}-04$ \\
\hline Ac-227** & No yield & $<5.23 \mathrm{E}-04$ & Upper limit & \\
\hline
\end{tabular}

** While analyses of these isotopes is needed, meeting the detection limits for these isotopes is a lower priority than meeting detection limits for the other specified isotopes.

Table 15. Tank 5F Composite Sample \#2: Challenging Radiological Constituents, $\mu \mathrm{Ci} / \mathrm{g}$.

\begin{tabular}{|c|c|c|c|c|}
\hline Analytes & Blank & $\begin{array}{c}\text { Tank 5 F } \\
\text { Composite \# 2 }\end{array}$ & $\begin{array}{c}\text { One Sigma } \\
\text { \%Uncertainty }\end{array}$ & $\begin{array}{c}\text { Targeted Minimum } \\
\text { Detection Limits }\end{array}$ \\
\hline Al-26 & $<9.77 \mathrm{E}-03$ & $<1.31 \mathrm{E}-02$ & MDA & $1.0 \mathrm{E}-03$ \\
\hline Cl-36 & $<2.43 \mathrm{E}-02$ & $<5.05 \mathrm{E}-03$ & Upper limit & $1.0 \mathrm{E}-03$ \\
\hline K-40 & $<5.54 \mathrm{E}-04$ & $<3.71 \mathrm{E}-03$ & MDA & $1.0 \mathrm{E}-03$ \\
\hline Nb-94 & $<5.33 \mathrm{E}-03$ & $<2.11 \mathrm{E}-03$ & MDA & $3.0 \mathrm{E}-03$ \\
\hline Sn-126 & $<3.57 \mathrm{E}-02$ & $<8.51 \mathrm{E}-01$ & MDA & $1.0 \mathrm{E}-03$ \\
\hline Sb-126 & $<1.14 \mathrm{E}-02$ & $<1.04 \mathrm{E}-01$ & MDA & $1.0 \mathrm{E}-03$ \\
\hline Sb-126m & $<1.14 \mathrm{E}-02$ & $<1.04 \mathrm{E}-01$ & MDA & $1.0 \mathrm{E}-03$ \\
\hline Eu-152 & $<2.95 \mathrm{E}-02$ & $<1.47 \mathrm{E}-01$ & MDA & $7.0 \mathrm{E}-03$ \\
\hline Pt-193 & $<8.12 \mathrm{E}-04$ & $<4.24 \mathrm{E}-04$ & MDA & $1.0 \mathrm{E}-03$ \\
\hline Ra-226** & No yield & $<6.81 \mathrm{E}-04$ & MDA & $5.0 \mathrm{E}-03$ \\
\hline Ac-227** & No yield & $<9.50 \mathrm{E}-05$ & Upper limit & $1.30 \mathrm{E}-04$ \\
\hline
\end{tabular}

** While analyses of these isotopes is needed, meeting the detection limits for these isotopes is a lower priority than meeting detection limits for the other specified isotopes.

Table 16. Tank 5F Composite Sample \#3: Challenging Radiological Constituents, $\mu \mathrm{Ci} / \mathrm{g}$.

\begin{tabular}{|c|c|c|c|c|}
\hline Analytes & Blank & $\begin{array}{l}\text { Tank 5F } \\
\text { Composite No. 3 }\end{array}$ & $\begin{array}{c}\text { One Sigma } \\
\text { \%Uncert. }\end{array}$ & $\begin{array}{c}\text { Targeted Minimum } \\
\text { Detection Limits }\end{array}$ \\
\hline Al-26 & $<9.77 \mathrm{E}-03$ & $<1.94 \mathrm{E}-02$ & MDA & $1.0 \mathrm{E}-03$ \\
\hline Cl-36 & $<2.43 \mathrm{E}-02$ & $<8.42 \mathrm{E}-03$ & Upper limit & $1.0 \mathrm{E}-03$ \\
\hline K-40 & $<5.54 \mathrm{E}-04$ & $<8.24 \mathrm{E}-04$ & MDA & $1.0 \mathrm{E}-03$ \\
\hline $\mathbf{N b - 9 4}$ & $<5.33 \mathrm{E}-03$ & $<1.14 \mathrm{E}-03$ & MDA & $3.0 \mathrm{E}-03$ \\
\hline Sn-126 & $<3.57 \mathrm{E}-02$ & $<1.18 \mathrm{E}+00$ & MDA & $1.0 \mathrm{E}-03$ \\
\hline Sb-126 & $<1.14 \mathrm{E}-02$ & $<1.50 \mathrm{E}-01$ & MDA & $1.0 \mathrm{E}-03$ \\
\hline Sb-126m & $<1.14 \mathrm{E}-02$ & $<1.50 \mathrm{E}-01$ & MDA & $1.0 \mathrm{E}-03$ \\
\hline Eu-152 & $<2.95 \mathrm{E}-02$ & $<2.11 \mathrm{E}-01$ & MDA & $7.0 \mathrm{E}-03$ \\
\hline Pt-193 & $<8.12 \mathrm{E}-04$ & $<1.56 \mathrm{E}-03$ & MDA & $1.0 \mathrm{E}-03$ \\
\hline Ra-226** & No yield & $<2.44 \mathrm{E}-03$ & MDA & $5.0 \mathrm{E}-03$ \\
\hline Ac-227** & No yield & $<1.65 \mathrm{E}-04$ & Upper limit & $1.30 \mathrm{E}-04$ \\
\hline
\end{tabular}

** While analyses of these isotopes is needed, meeting the detection limits for these isotopes is a lower priority than meeting detection limits for the other specified isotopes. 


\subsection{CONCLUSIONS}

Page 32 of 50

Tank 5F composite samples were analyzed for radiological, elemental and chemical constituents. Where analytical methods yielded additional contaminants other than those requested by the customer, these results are also reported.

The target detection limits for isotopes analyzed were based on customer desired detection limits as specified in the technical task request documents. While many of the target detection limits, as specified in the technical task request and task technical and quality assurance plans were met for the species characterized for Tank 5F, some were not met. In a number of cases, the relatively high levels of radioactive species of the same element or a chemically similar element precluded the ability to measure some isotopes to low levels. The isotopes whose minimum detection limits were not met in all cases included the following: Al-26, Sn-126, Sb-126, Sb-126m, Eu-152 and Cf-249. The TTR allows that while the analyses of these isotopes is needed, meeting the detection limits for these isotopes is a lower priority than meeting detection limits for the other specified isotopes. However, SRNL, in conjunction with the customer, reviewed the few cases where the detection limit goals were not met and determined that the impacts were negligible. [SRR-CWDA-2012-00013]

\subsection{QUALITY ASSURANCE}

The Task Technical and Quality Assurance Plan details the planned activities and associated quality assurance implementing procedures for the characterization of Tank 5F (TTQAP, SRNL-RP-2010-01695, Rev. 1). Laboratory Notebook SRNL-NB-2011-00125, WSRC-NB2001-00142 and various AD notebooks contain the experimental data. Other relevant QA documents include the Technical Task Request (HLE-TTR-2010-004, Rev 7), Tank 5 Sampling and Analysis Plan-SRR-LWE-2010-00285, Rev. 1, November 15, 2010 and Tank 5 Composite Sample Volumetric Proportions, SRR-CWDA-2011-00067, Rev.1 April 20, 2011.

\subsection{ACKNOWLEDGEMENTS}

The authors thank Analytical Development Section personnel, in particular, Curtis Johnson, and Cecilia Diprete, for performing actinide and other metal analyses. We also thank the shielded cell operations personnel, in particular, Linda Bush, Mary H. Beasley and Kevin Reid for their work with the Tank 5F samples in the shielded cells. 
APPENDIX A-0: AD Tank 5F Characterization Tracking Numbers

\begin{tabular}{|c|c|c|}
\hline Analytes & Method (s) & $\begin{array}{l}\text { SRNL AD Tracking } \\
\text { Number (LIMS) }\end{array}$ \\
\hline Total Alpha & Rad Screen & $300286107-300286121$ \\
\hline Non-volatile Beta & Rad Screen & $300286107-300286121$ \\
\hline $\mathrm{Al}-26$ & GAMMA SPEC Cs REMOVED & $300286107-300286120$ \\
\hline Cl-36 & Cl-36 & $300292253-300292262$ \\
\hline $\mathrm{K}-40$ & $\mathrm{~K}-40$ & 300293878- 300293896 \\
\hline Sr-90 & Sr-90 & $300286107-300286120$ \\
\hline Pu-238 & $\mathrm{Pu}-238 / 241$ & $300286107-300286121$ \\
\hline Pu-241 & Pu-238/241 & $300286107-300286121$ \\
\hline Cs-137 & GAMMA SPEC & $300286107-300286121$ \\
\hline $\mathrm{U}-232$ & $\mathrm{U}-232$ & $300286107-300286121$ \\
\hline U-233 & U-233, U-234, U-235, U-236 & $300286107-300286116$ \\
\hline $\mathrm{U}-234$ & U-233, U-234, U-235, U-236 & $300286107-300286116$ \\
\hline U-235 & U-233, U-234, U-235, U-236 & $300286107-300286116$ \\
\hline $\mathrm{U}-236$ & U-233, U-234, U-235, U-236 & $300286107-300286116$ \\
\hline $\mathrm{U}-238$ & ICP-MS & $300286107-300286116$ \\
\hline Co-60 & GAMMA SPEC Cs REMOVED & $300286107-300286120$ \\
\hline Sb-126 & GAMMA SPEC Cs REMOVED & $300286107-300286120$ \\
\hline Sn-126 & GAMMA SPEC Cs REMOVED & $300286107-300286120$ \\
\hline Eu-152 & GAMMA SPEC Cs REMOVED & $300286107-300286120$ \\
\hline Eu-154 & GAMMA SPEC Cs REMOVED & $300286107-300286120$ \\
\hline Eu-155 & GAMMA SPEC Cs REMOVED & $300286107-300286120$ \\
\hline Am-241 & Gamma Spec. & $300286107-300286120$ \\
\hline Pu-239 & Pu-242/244 & $300286107-300286116$ \\
\hline Pu-240 & Pu-242/244 & $300286107-300286116$ \\
\hline $\begin{array}{l}\mathrm{Pu}-242 \\
\end{array}$ & Pu-242/244 & $300286107-300286116$ \\
\hline Pu-244 & Pu-242/244 & $300286107-300286116$ \\
\hline $\mathrm{Pu}-239 / 240$ & Pu-TTA & $300286107-300286121$ \\
\hline PM-147/ SM-151 & Pm-147/Sm-151 & $300286107-300286121$ \\
\hline Tritium & TRITIUM & $300286123-300286135$ \\
\hline $\mathrm{Ni}-59$ & $\mathrm{Ni}-59,63$ & $300286123-300286135$ \\
\hline $\mathrm{Ni}-63$ & Ni-59,63 & $300286123-300286135$ \\
\hline Tc-99 & Tc-99 & $300294396-300294405$ \\
\hline I-129 & $\mathrm{I}-129$ & $300288706-300288716$ \\
\hline Cs-135 & Cs-135 & $300286107-300286120$ \\
\hline Carbon-14 & Carbon-14 & $\begin{array}{l}300294468-300294482 \\
300294509-300294521\end{array}$ \\
\hline Se-79 & Se-79 & $300292711-300292720$ \\
\hline Zr-93 & Zr-93 & $300286107-300286121$ \\
\hline Pd-107 & Pd-107 & $300291713-300291722$ \\
\hline Pt-193 & Pt-193 & $300286107-300286120$ \\
\hline
\end{tabular}


SRNL-STI-2012-00034, Rev. 1 August 3, 2012

Page 34 of 50

APPENDIX A-0: AD Tank 5F Characterization Tracking Numbers-Continued

\begin{tabular}{|c|c|c|}
\hline Analytes & Method (s) & $\begin{array}{c}\text { SRNL AD Tracking } \\
\text { Number (LIMS) }\end{array}$ \\
\hline $\mathrm{Nb}-94$ & Nb-94 & $300286107-300286121$ \\
\hline $\mathrm{Am} / \mathrm{Cm}$ & $\mathrm{Am} / \mathrm{Cm}$ & $300290171-300290180$ \\
\hline $\mathrm{Ra}-226$ & $\mathrm{Ra}-226$ & $300294754-300294773$ \\
\hline $\mathrm{Th}-229 / 230$ & Th-229/230 & $300291231-300291248$ \\
\hline $\mathrm{Ac}-227$ & Ac-227 & $300291231-300291248$ \\
\hline $\mathrm{Pa}-231$ & $\mathrm{~Pa}-231$ & $300293293-300293311$ \\
\hline $\mathrm{Np}-237$ & ICP-MS \& Np-239 decay correction & $300286107-300286121$ \\
\hline $\mathrm{Hg}$ & $\mathrm{CVAA} \mathrm{Hg}$ & $300286123-300286135$ \\
\hline $\mathrm{Se}$ & AASe & $300286123-300286137$ \\
\hline As & AASe & $300286123-300286137$ \\
\hline Cations & ICP-MS-PF digestions & $300286107-300286121$ \\
\hline Cations & ICP-MS-AQR digestions & $300286123-300286136$ \\
\hline Cations & ICP-ES-AQR digestions & $300286123-300286137$ \\
\hline Cations & ICP-ES-PF digestions & $300286107-300286120$ \\
\hline Anions & IC- Leachate analysis & $300287323-300287337$ \\
\hline
\end{tabular}


SRNL-STI-2012-00034, Rev. 1

August 3, 2012

Page 35 of 50

\section{APPENDIX A-1: Chemical Composition of Reference Tank 8 Simulant}

\begin{tabular}{|c|c|c|c|c|}
\hline & $\begin{array}{c}\text { Analytical Results for } \\
\text { Tank 8 Simulant Sludge }\end{array}$ & $\begin{array}{c}\text { Standard } \\
\text { deviation }\end{array}$ & $\begin{array}{c}\text { Nominal Recipe for Tank 8 } \\
\text { Simulant Sludge }\end{array}$ & $\begin{array}{c}\text { Percent Relative } \\
\text { Deviation }\end{array}$ \\
\hline Average & & wt. \% & 0.47 \\
\hline Constituent & wt. \% & & 9.0 & 5.3 \\
\hline $\mathrm{Al}$ & 9.5 & 0.06 & 0.24 & 1.2 \\
\hline $\mathrm{Ba}$ & 0.25 & 0.00 & 2.1 & 4.2 \\
\hline $\mathrm{Ca}$ & 2.3 & 0.01 & 0.24 & 0.20 \\
\hline $\mathrm{Cr}$ & 0.26 & 0.00 & 0.13 & 0.22 \\
\hline $\mathrm{Cu}$ & 0.13 & 0.01 & 24 & 38 \\
\hline $\mathrm{Fe}$ & 27 & 0.20 & 0.005 & 2.5 \\
\hline$* \mathrm{~K}$ & 0.038 & 0.00 & 0.12 & 1.9 \\
\hline $\mathrm{Mg}$ & 0.13 & 0.00 & 2.7 & 4.8 \\
\hline $\mathrm{Mn}$ & 2.8 & 0.02 & 7.4 & 0.36 \\
\hline$* \mathrm{Na}$ & 6.1 & 0.06 & 2.8 & 11 \\
\hline$* \mathrm{Ni}$ & 2.8 & 0.02 & 0.21 & 0.28 \\
\hline $\mathrm{Pb}$ & 0.16 & 0.01 & 0.76 & 3.7 \\
\hline $\mathrm{Si}$ & 0.88 & 0.01 & 0.09 & 8.8 \\
\hline $\mathrm{Sr}$ & 0.093 & 0.00 & 0.27 & \\
\hline $\mathrm{Zn}$ & 0.31 & 0.02 & & \\
\hline $\mathrm{Aq} r g i a n$ & & & \\
\hline
\end{tabular}

* Aqua regia digestion data; all other data from Peroxide fusion. . Note that the moisture content of the Tank 8 simulant sludge (89.2\%) was taken into account when calculating the weight percent values. 
SRNL-STI-2012-00034, Rev. 1

August 3, 2012

Page 36 of 50

APPENDIX A-2: Chemical Composition of Analyzed Reference Glass

\begin{tabular}{|c|c|c|c|c|}
\hline & $\begin{array}{c}\text { Analytical Results for } \\
\text { Reference Glass (ARG) }\end{array}$ & $\begin{array}{l}\text { Standard } \\
\text { deviation }\end{array}$ & $\begin{array}{c}\text { Nominal Recipe for } \\
\text { Reference Glass (ARG) }\end{array}$ & $\begin{array}{c}\text { Percent Relative } \\
\text { Deviation }\end{array}$ \\
\hline & Average & & & \%RD \\
\hline Constituent & wt. $\%$ & & wt. \% & \\
\hline $\mathrm{Al}$ & 2.5 & 0.05 & 2.5 & 0.27 \\
\hline B & 2.5 & 0.05 & 2.7 & 2.1 \\
\hline $\mathrm{Ba}$ & 0.080 & 0.00 & 0.079 & 0.29 \\
\hline $\mathrm{Ca}$ & 1.6 & 0.01 & 1.02 & 10 \\
\hline $\mathrm{Cr}$ & 0.066 & 0.00 & 0.064 & 0.87 \\
\hline$* \mathrm{Cu}$ & 0.0025 & 0.00 & 0.003 & 4.7 \\
\hline $\mathrm{Fe}$ & 10 & 0.24 & 9.8 & 0.59 \\
\hline$* \mathrm{~K}$ & 2.3 & 0.08 & 2.3 & 0.52 \\
\hline $\mathrm{Li}$ & 1.5 & 0.02 & 1.5 & 0.00 \\
\hline $\mathrm{Mg}$ & 0.53 & 0.02 & 0.52 & 0.66 \\
\hline $\mathrm{Mn}$ & 1.4 & 0.04 & 1.5 & 0.35 \\
\hline$* \mathrm{Na}$ & 8.6 & 0.29 & 8.5 & 0.31 \\
\hline$* \mathrm{Ni}$ & 0.83 & 0.04 & 0.83 & 0.06 \\
\hline$* \mathrm{P}$ & 0.090 & 0.00 & 0.11 & 4.9 \\
\hline $\mathrm{Si}$ & 23 & 0.97 & 22 & 0.62 \\
\hline $\mathrm{Sr}$ & 0.010 & 0.00 & 0.003 & 27 \\
\hline $\mathrm{Ti}$ & 0.63 & 0.07 & 0.69 & 2.4 \\
\hline $\mathrm{Zn}$ & 0.046 & 0.00 & 0.016 & 24 \\
\hline
\end{tabular}

* Aqua regia digestion data; all other data from Peroxide fusion.

\section{Natural cadmium concentration by MS Tank 5F COMPOSITE 1}

The main Cd isotopes used for calculations are masses 110, 111, 112, 114 and 105

(contribution from Pd-105).

1. ([Cd-110] - [(Pd-105)] * ffission yield for mass $110 * 110 /$ fission yield for mass $105 * 105\}]) / \mathrm{Cd}-110$ stable abundance of $12.49 \%$ or 0.1249 .

2. $\mathrm{Cd}-111 / 0.128$

3. Cd-112/0.2413

4. Cd-114/0.2873

5. Cd-116/0.0758

Values obtained through steps 1 and 5 above were averaged. 
SRNL-STI-2012-00034, Rev. 1

August 3, 2012

Page 37 of 50

Typical Cd calculations for Tank 5F Composite 1-1

1. $([17.8]-[22.8)] *\{0.025 * 110 / 0.96 * 105\}]) / 0.1249$.

$=[17.8-(22.8 * 0.0273)] / 0.1249$

$=137.53 \mathrm{ug} / \mathrm{g}$ or $0.1375 \mathrm{mg} / \mathrm{g}$

2. $22.3 / 0.128=174.2 \mathrm{ug} / \mathrm{g}$ or $0.174 \mathrm{mg} / \mathrm{g}$

3. $29.9 / 0.2413=123.9 \mathrm{ug} / \mathrm{g}$ or $0.1239 \mathrm{~m} / \mathrm{g}$

4. $21.1 / 0.2873=73.44 \mathrm{ug} / \mathrm{g}$ or $0.073 \mathrm{mg} / \mathrm{g}$

5. $8.5 / 0.0758=112.14$ or $0.1121 \mathrm{mg} / \mathrm{g}$

6. Average of all values comes to 0.12

Using the similar approach the calculations were performed for Tank 5 composite sample 2 and 3. Results are summarized in table below for Cd by MS and Cd by ICPES.

\begin{tabular}{|c|c|c|c|c|}
\hline & $\begin{array}{l}300286107 \\
\text { COMPOSITE 1- } \\
\text { 1-PF, mg/g }\end{array}$ & $\begin{array}{l}300286108 \\
\text { COMPOSITE } \\
1-2-P F, \mathrm{mg} / \mathrm{g} \\
\end{array}$ & $\begin{array}{l}300286109 \\
\text { COMPOSITE } \\
1-3-P F, \mathrm{mg} / \mathrm{g} \\
\end{array}$ & Averages \\
\hline Cd by ICP-MS & 0.12 & 0.13 & 0.11 & 0.12 \\
\hline Cd by ICP-ES & 0.081 & 0.092 & 0.097 & 0.090 \\
\hline \%RD & 39 & 34 & 13 & 29 \\
\hline
\end{tabular}

The average percent relative deviation for cadmium concentrations based on ICP-MS and ICP-ES are about $29 \%$.

\section{Natural barium concentration by MS}

Main stable Ba isotopes used for calculations are masses 136, 137 and 138

[Sum of MS signals from masses $136+137+138]$ ]

Tank 5F Composite No. 1, unit of ug/g sample

Run $114.4+297+1960=2,271.4=2.271 \mathrm{mg} / \mathrm{g}$

Run $213.9+301+1880=2,194.9=2.195 \mathrm{mg} / \mathrm{g}$

Run $30+261+1660=1921=1.921 \mathrm{mg} / \mathrm{g}$

\begin{tabular}{|l|l|l|c|c|}
\hline & $\begin{array}{l}\text { 300286107 } \\
\text { COMPOSITE } \\
\text { 1-1-PF, mg/g }\end{array}$ & $\begin{array}{l}\text { 300286108 } \\
\text { COMPOSITE } \\
\text { 1-2-PF, } \mathrm{mg} / \mathrm{g}\end{array}$ & $\begin{array}{l}\text { 300286109 } \\
\text { COMPOSITE } \\
\text { 1-3-PF, } \mathrm{mg} / \mathrm{g}\end{array}$ & Averages \\
\hline Ba by ICP-MS & 2.3 & 2.2 & 1.9 & 2.1 \\
\hline Ba by ICP-ES & 1.7 & 2.0 & 2.1 & 1.9 \\
\hline \%RD & 26.5 & 10.8 & 7.5 & $\mathbf{9 . 9}$ \\
\hline
\end{tabular}

The average percent relative deviation for barium concentrations based on ICP-MS and ICPES is over $9.9 \%$. 
Natural Lanthanum concentration by MS

Main stable La isotopes used for calculations is mass 139

[Sum of MS signals from masses 139]

Tank 5F Composite No. 1, unit of ug/g sample

Run 11540 ug/g = 1.540 mg/g

Run $21480 \mathrm{ug} / \mathrm{g}=1.48 \mathrm{mg} / \mathrm{g}$

Run $31370=1.370 \mathrm{mg} / \mathrm{g}$

\begin{tabular}{|l|l|l|l|l|}
\hline & $\begin{array}{l}300286107 \\
\text { COMPOSITE } \\
\text { 1-1-PF, } \mathrm{mg} / \mathrm{g}\end{array}$ & $\begin{array}{l}\text { 300286108 } \\
\text { COMPOSITE } \\
\text { 1-2-PF, } \mathrm{mg} / \mathrm{g}\end{array}$ & $\begin{array}{l}\text { 300286109 } \\
\text { COMPOSITE } \\
\text { 1-3-PF, } \mathrm{mg} / \mathrm{g}\end{array}$ & Averages \\
\hline La by ICP-MS & 1.5 & 1.5 & 1.4 & 1.5 \\
\hline La by ICP-ES & 1.3 & 1.4 & 1.5 & 1.4 \\
\hline \%RD & 15 & 7.0 & 5.7 & $\mathbf{4 . 9}$ \\
\hline
\end{tabular}

The average percent relative deviation for lanthanum concentrations based on ICP-MS and ICP-ES is $4.9 \%$. 
SRNL-STI-2012-00034, Rev. 1

August 3, 2012

Page 39 of 50

\section{APPENDIX A-3: Analytical Results for Challenging Radiological Constituents}

\section{Challenging Radiological Constituents for Tank 5F Composite Sample \#1, $\mu \mathrm{Ci} / \mathrm{g}$.}

\begin{tabular}{|c|c|c|c|c|c|c|c|}
\hline Analytes & Blank & Run 1 & Run 2 & Run 3 & Average & $\begin{array}{c}\text { One Sigma } \\
\text { \%Uncert. }\end{array}$ & $\begin{array}{c}\text { Targeted } \\
\text { Minimum } \\
\text { Detection Limits }\end{array}$ \\
\hline Al-26 & $<9.77 \mathrm{E}-03$ & $<1.29 \mathrm{E}-02$ & $<2.32 \mathrm{E}-02$ & $<2.03 \mathrm{E}-02$ & $<\mathbf{1 . 8 8 E}-\mathbf{0 2}$ & MDA & $1.0 \mathrm{E}-03$ \\
\hline Cl-36 & $<2.43 \mathrm{E}-02$ & $<3.76 \mathrm{E}-02$ & $<7.21 \mathrm{E}-03$ & $<2.87 \mathrm{E}-03$ & $<\mathbf{1 . 5 9 E}-\mathbf{0 2}$ & Upper limit & $1.0 \mathrm{E}-03$ \\
\hline K-40 & $<5.54 \mathrm{E}-04$ & $<5.14 \mathrm{E}-03$ & $<6.17 \mathrm{E}-03$ & $<7.25 \mathrm{E}-03$ & $<\mathbf{6 . 1 9 E}-\mathbf{0 3}$ & MDA & $1.0 \mathrm{E}-03$ \\
\hline Nb-94 & $<5.33 \mathrm{E}-03$ & no yield & $<2.87 \mathrm{E}-03$ & $<4.85 \mathrm{E}-02$ & $<2.57 \mathrm{E}-\mathbf{0 2}$ & MDA & $3.0 \mathrm{E}-03$ \\
\hline Sn-126 & $<3.57 \mathrm{E}-02$ & $<8.74 \mathrm{E}-01$ & $<8.06 \mathrm{E}-01$ & $<1.23 \mathrm{E}+00$ & $<\mathbf{9 . 6 8 E}-\mathbf{0 1}$ & MDA & $1.0 \mathrm{E}-03$ \\
\hline Sb-126 & $<1.14 \mathrm{E}-02$ & $<1.09 \mathrm{E}-01$ & $<1.58 \mathrm{E}-01$ & $<1.50 \mathrm{E}-01$ & $<\mathbf{1 . 3 9 E}-\mathbf{0 1}$ & MDA & $1.0 \mathrm{E}-03$ \\
\hline Sb-126m & $<1.14 \mathrm{E}-02$ & $<1.09 \mathrm{E}-01$ & $<1.58 \mathrm{E}-01$ & $<1.50 \mathrm{E}-01$ & $<\mathbf{1 . 3 9 E}-\mathbf{0 1}$ & MDA & $1.0 \mathrm{E}-03$ \\
\hline Eu-152 & $<2.95 \mathrm{E}-02$ & $<2.23 \mathrm{E}-01$ & $<2.11 \mathrm{E}-01$ & $<2.20 \mathrm{E}-01$ & $<\mathbf{2 . 1 8 E}-\mathbf{0 1}$ & MDA & $7.0 \mathrm{E}-03$ \\
\hline Ra-226 & No yield & No yield & No yield & $<9.78 \mathrm{E}-03$ & $<\mathbf{9 . 7 8 E}-\mathbf{0 3}$ & MDA & $5.0 \mathrm{E}-03$ \\
\hline Pt-193 & $<8.12 \mathrm{E}-04$ & $<6.37 \mathrm{E}-04$ & $<6.95 \mathrm{E}-04$ & $<4.91 \mathrm{E}-04$ & $<\mathbf{6 . 0 8 E}-\mathbf{0 4}$ & MDA & $1.0 \mathrm{E}-03$ \\
\hline Ac-227 & No yield & $<5.23 \mathrm{E}-04$ & $<4.73 \mathrm{E}-02$ & $<7.07 \mathrm{E}-04$ & $<\mathbf{1 . 6 2 E}-\mathbf{0 2}$ & Upper limit & $1.30 \mathrm{E}-04$ \\
\hline
\end{tabular}

Challenging Radiological Constituents for Tank 5F Composite Sample \#2, $\mu \mathrm{Ci} / \mathrm{g}$.

\begin{tabular}{|c|l|l|l|l|l|c|c|}
\hline Analytes & Blank & Run 1 & Run 2 & Run 3 & Average & $\begin{array}{c}\text { One Sigma } \\
\text { \%Uncert. }\end{array}$ & $\begin{array}{c}\text { Targeted } \\
\text { Minimum } \\
\text { Detection Limits }\end{array}$ \\
\hline Al-26 & $<9.77 \mathrm{E}-03$ & $<1.73 \mathrm{E}-02$ & $<1.31 \mathrm{E}-02$ & $<1.87 \mathrm{E}-02$ & $<\mathbf{1 . 6 4 E - 0 2}$ & MDA & $1.0 \mathrm{E}-03$ \\
\hline Cl-36 & $<2.43 \mathrm{E}-02$ & $<1.86 \mathrm{E}-02$ & $<5.05 \mathrm{E}-03$ & $<3.89 \mathrm{E}-02$ & $<\mathbf{2 . 0 9 E}-\mathbf{0 2}$ & Upper limit & $1.0 \mathrm{E}-03$ \\
\hline K-40 & $<5.54 \mathrm{E}-04$ & $<3.71 \mathrm{E}-03$ & $<4.00 \mathrm{E}-03$ & $<4.86 \mathrm{E}-03$ & $<\mathbf{4 . 1 9 E}-\mathbf{0 3}$ & MDA & $1.0 \mathrm{E}-03$ \\
\hline Nb-94 & $<5.33 \mathrm{E}-03$ & No yield & $<2.11 \mathrm{E}-03$ & $<4.58 \mathrm{E}-02$ & $<\mathbf{2 . 4 0 E}-\mathbf{0 2}$ & MDA & $3.0 \mathrm{E}-03$ \\
\hline Sn-126 & $<3.57 \mathrm{E}-02$ & $<1.27 \mathrm{E}+00$ & $<8.51 \mathrm{E}-01$ & $<1.24 \mathrm{E}+00$ & $<\mathbf{1 . 1 2 E}+\mathbf{0 0}$ & MDA & $1.0 \mathrm{E}-03$ \\
\hline Sb-126 & $<1.14 \mathrm{E}-02$ & $<1.57 \mathrm{E}-01$ & $<1.04 \mathrm{E}-01$ & $<1.54 \mathrm{E}-01$ & $<\mathbf{1 . 3 8 E}-\mathbf{0 1}$ & MDA & $1.0 \mathrm{E}-03$ \\
\hline Sb-126m & $<1.14 \mathrm{E}-02$ & $<1.57 \mathrm{E}-01$ & $<1.04 \mathrm{E}-01$ & $<1.54 \mathrm{E}-01$ & $<\mathbf{1 . 3 8 E}-\mathbf{0 1}$ & MDA & $1.0 \mathrm{E}-03$ \\
\hline Eu-152 & $<2.95 \mathrm{E}-02$ & $<2.24 \mathrm{E}-01$ & $<1.47 \mathrm{E}-01$ & $<2.26 \mathrm{E}-01$ & $<\mathbf{1 . 9 9 E}-\mathbf{0 1}$ & MDA & $7.0 \mathrm{E}-03$ \\
\hline Pt-193 & $<8.12 \mathrm{E}-04$ & $<1.78 \mathrm{E}-03$ & $<2.74 \mathrm{E}-03$ & $<4.24 \mathrm{E}-04$ & $<\mathbf{1 . 6 5 E}-\mathbf{0 3}$ & MDA & $1.0 \mathrm{E}-03$ \\
\hline Ra-226 & No yield & $<6.81 \mathrm{E}-04$ & $<8.63 \mathrm{E}-04$ & No yield & $<7.72 \mathrm{E}-\mathbf{0 4}$ & MDA & $5.0 \mathrm{E}-03$ \\
\hline Ac-227 & No yield & $<1.34 \mathrm{E}-04$ & $<6.08 \mathrm{E}-04$ & $<9.50 \mathrm{E}-05$ & $<\mathbf{2 . 7 9 E - 0 4}$ & Upper limit & $1.30 \mathrm{E}-04$ \\
\hline
\end{tabular}


SRNL-STI-2012-00034, Rev. 1

August 3, 2012

Page 40 of 50

Challenging Radiological Constituents for Tank 5F Composite Sample \#3, $\underline{\mu \mathrm{Ci} / \mathrm{g} .}$

\begin{tabular}{|c|c|c|c|c|c|c|c|}
\hline Analytes & Blank & Run 1 & Run 2 & Run 3 & Average & $\begin{array}{l}\text { One Sigma } \\
\% \text { Uncert. }\end{array}$ & $\begin{array}{c}\text { Targeted } \\
\text { Minimum } \\
\text { Detection } \\
\text { Limits }\end{array}$ \\
\hline Al-26 & $<9.77 \mathrm{E}-03$ & $<2.01 \mathrm{E}-02$ & $<1.98 \mathrm{E}-02$ & $<1.94 \mathrm{E}-02$ & $<1.98 \mathrm{E}-02$ & MDA & 1.0E-03 \\
\hline Cl-36 & $<2.43 \mathrm{E}-02$ & $<1.22 \mathrm{E}-02$ & $<8.42 \mathrm{E}-03$ & $<1.81 \mathrm{E}-02$ & $<1.29 \mathrm{E}-02$ & Upper limit & $1.0 \mathrm{E}-03$ \\
\hline $\mathrm{K}-40$ & $<5.54 \mathrm{E}-04$ & $<6.62 \mathrm{E}-03$ & $<8.24 \mathrm{E}-04$ & $<9.41 \mathrm{E}-04$ & $<2.80 \mathrm{E}-03$ & MDA & $1.0 \mathrm{E}-03$ \\
\hline Nb-94 & $<5.33 E-03$ & no yield & $<1.14 \mathrm{E}-03$ & $<3.89 \mathrm{E}-02$ & $<2.00 \mathrm{E}-02$ & MDA & 3.0E-03 \\
\hline Sn-126 & $<3.57 \mathrm{E}-02$ & $<1.18 \mathrm{E}+00$ & $<1.18 \mathrm{E}+00$ & $<1.18 \mathrm{E}+00$ & $<1.18 \mathrm{E}+00$ & MDA & $1.0 \mathrm{E}-03$ \\
\hline Sb-126 & $<1.14 \mathrm{E}-02$ & $<1.53 \mathrm{E}-01$ & $<1.50 \mathrm{E}-01$ & $<1.53 \mathrm{E}-01$ & $<1.52 \mathrm{E}-01$ & MDA & $1.0 \mathrm{E}-03$ \\
\hline Sb-126m & $<1.14 \mathrm{E}-02$ & $<1.53 \mathrm{E}-01$ & $<1.50 \mathrm{E}-01$ & $<1.53 \mathrm{E}-01$ & $<1.52 \mathrm{E}-01$ & MDA & 1.0E-03 \\
\hline Eu-152 & $<2.95 \mathrm{E}-02$ & $<2.23 \mathrm{E}-01$ & $<2.11 \mathrm{E}-01$ & $<2.20 \mathrm{E}-01$ & $<2.18 \mathrm{E}-01$ & MDA & 7.0E-03 \\
\hline Pt-193 & $<8.12 \mathrm{E}-04$ & $<1.56 \mathrm{E}-03$ & $<3.48 \mathrm{E}-03$ & $<6.35 \mathrm{E}-03$ & $<3.80 \mathrm{E}-03$ & MDA & $1.0 \mathrm{E}-03$ \\
\hline Ra-226 & No yield & $<2.44 \mathrm{E}-03$ & $<9.01 \mathrm{E}-03$ & No yield & $<5.73 \mathrm{E}-03$ & MDA & 5.0E-03 \\
\hline Ac-227 & No yield & $<1.65 \mathrm{E}-04$ & $<3.04 \mathrm{E}-04$ & $<1.35 \mathrm{E}-03$ & $<6.05 E-04$ & Upper limit & $1.30 \mathrm{E}-04$ \\
\hline
\end{tabular}


SRNL-STI-2012-00034, Rev. 1

August 3, 2012

Page 41 of 50

\section{APPENDIX A-4: “As-received” and Composited Sample Bulk Densities, g/mL}

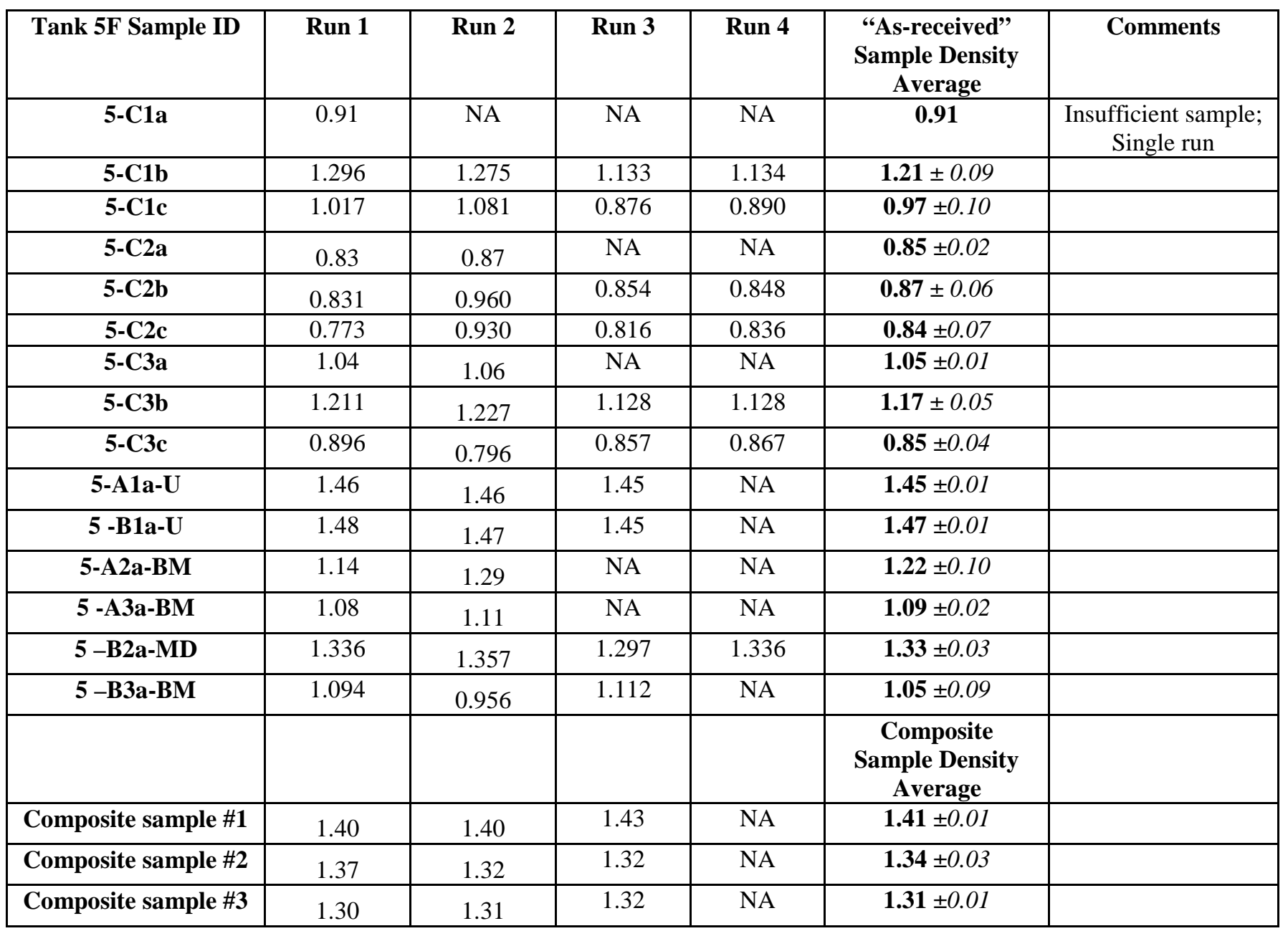


SRNL-STI-2012-00034, Rev. 1 August 3, 2012

Page 42 of 50

\section{APPENDIX A-5: Tank 5F Homogenized Discrete Sample, Composited Sample Bulk} Densities $(\mathrm{g} / \mathrm{mL})$ and Composited Sample weight percent solids

\begin{tabular}{|c|c|c|c|c|}
\hline Tank 5F Sample ID & Run 1 & Run 2 & Run 3 & $\begin{array}{c}\text { Homogenized Sample } \\
\text { Density Average, g/mL }\end{array}$ \\
\hline 5-C1a & 1.08 & 1.00 & 1.04 & $1.04 \pm 0.04$ \\
\hline 5-C1b & 1.120 & 1.100 & 1.097 & $1.11 \pm 0.01$ \\
\hline 5-C1c & 0.981 & 0.999 & 0.868 & $\mathbf{0 . 9 5} \pm 0.07$ \\
\hline $5-\mathrm{C} 2 \mathrm{a}$ & 1.06 & 1.01 & 0.99 & $1.02 \pm 0.04$ \\
\hline 5-C2b & 0.993 & 0.972 & 0.939 & $\mathbf{0 . 9 7} \pm 0.03$ \\
\hline 5-C2c & 0.978 & 0.915 & 0.898 & $0.93 \pm 0.04$ \\
\hline 5-C3a & 1.13 & 1.13 & 1.06 & $1.11 \pm 0.04$ \\
\hline 5-C3b & 1.08 & 0.97 & 1.03 & $1.03 \pm 0.06$ \\
\hline 5-С3c & 0.98 & 0.93 & 0.97 & $\mathbf{0 . 9 6} \pm 0.03$ \\
\hline 5-A1a-U & 1.43 & 1.45 & 1.42 & $1.43 \pm 0.02$ \\
\hline 5 -B1a-U & 1.43 & 1.43 & 1.45 & $1.44 \pm 0.01$ \\
\hline 5-A2a-BM & 1.26 & 1.26 & 1.25 & $1.25 \pm 0.01$ \\
\hline 5 -АЗа-BM & 1.05 & 1.04 & 1.04 & $1.05 \pm 0.00$ \\
\hline 5-B2a-MD & 1.14 & 1.14 & 1.19 & $1.16 \pm 0.03$ \\
\hline \multirow[t]{2}{*}{ 5-BЗа-BM } & 1.21 & 1.26 & 1.26 & $1.24 \pm 0.03$ \\
\hline & & & & $\begin{array}{l}\text { Composite Sample } \\
\text { Density Average }\end{array}$ \\
\hline Composite sample \#1 & 1.40 & 1.40 & 1.43 & $1.41 \pm 0.01$ \\
\hline Composite sample \#2 & 1.37 & 1.32 & 1.32 & $1.34 \pm 0.03$ \\
\hline \multirow[t]{2}{*}{ Composite sample \#3 } & 1.30 & 1.31 & 1.32 & $1.31 \pm 0.01$ \\
\hline & & & & $\begin{array}{c}\text { Composite Sample } \\
\text { Wt\%; Average }\end{array}$ \\
\hline Composite sample \#1 & 95.59 & 95.91 & 95.73 & $95.7 \pm 0.2$ \\
\hline Composite sample \#2 & 96.53 & 96.59 & 97.08 & $\mathbf{9 6 . 7} \pm 0.3$ \\
\hline Composite sample \#3 & 96.00 & 96.70 & 96.41 & $96.4 \pm 0.4$ \\
\hline
\end{tabular}


SRNL-STI-2012-00034, Rev. 1

August 3, 2012

Page 43 of 50

APPENDIX A-6: Tank 5F discrete and composite samples in stock.

COMPOSITE 1

5-A1a-U

5-B2a-MD

$5-\mathrm{C} 1 \mathrm{a}$

$5-\mathrm{C} 2 \mathrm{~b}$

$5-\mathrm{C} 3 \mathrm{c}$

COMPOSITE 2

5-A2a-BM

5-B3а-BM

$5-\mathrm{C} 1 \mathrm{~b}$

$5-\mathrm{C} 2 \mathrm{c}$

5-С3a

COMPOSITE 3

5-A3a-BM

5-B1a-U

5-C1c

5-C2a

5-C3b
Residuals Tank 5F sample, g

No sample left in stock

No sample left in stock

55

18

45

55

35

230

125

62

72

92

37

168

2

35

40

45 
SRNL-STI-2012-00034, Rev. 1

August 3, 2012

Page 44 of 50

\section{APPENDIX B: Summary of Analytical Methods}

\section{Aqua Regia Digestions (AQR)}

Samples were digested according to procedure L16.1, ADS-2226. In a typical digestion, $\sim 0.5 \mathrm{~g}$ of Tank $5 \mathrm{~F}$ composite sample was placed into a Teflon ${ }^{\circledR}$ digestion vessel. Then, $9 \mathrm{~mL}$ (hydrochloric acid) $\mathrm{HCl}$, and $3 \mathrm{~mL}$ (nitric acid) $\mathrm{HNO}_{3}$ were added to the Teflon ${ }^{\circledR}$ vessel. The Teflon ${ }^{\circledR}$ vessel was sealed and heated for a period of no more than 4 hours at $115{ }^{\circ} \mathrm{C}$. The sample was then cooled and diluted to $50 \mathrm{~mL}$. Three samples, in total, from each composite sample were digested by aqua regia.

\section{Sodium Peroxide/Hydroxide Fusions (PF)}

Samples were digested according to procedure L16.1, ADS 2502. In a typical digestion, $\sim 2$ grams of composite Tank 5F sample was placed into a nickel (Ni) crucible with a known weight. The material in the crucible was dried until two consecutive weights were within \pm 0.02 grams. The remaining material in the crucible was fused at $675^{\circ} \mathrm{C}$ using a mixture of sodium peroxide (6.0 grams) and sodium hydroxide (4.0 grams). After the sample was cooled, water was added to dissolve the fused material and the solution was acidified by the addition of $25 \mathrm{~mL} \mathrm{HCl}$. The sample was diluted to $100 \mathrm{~mL}$. Three samples, in total, from each composite sample were digested by sodium peroxide fusion.

\section{Inductively Coupled Plasma - Atomic Emission Spectroscopy (ICP-ES)}

Samples are diluted as necessary to bring analytes within the instrument range. A scandium internal standard is added to all samples after dilution at a concentration of $2 \mathrm{mg} / \mathrm{L}$. The instrument is calibrated daily with a blank and two standards: 5 and $10 \mathrm{mg} / \mathrm{L}$ NIST traceable multi-element standards in dilute acid. Background and internal standard correction were applied to the results.

\section{Ion Chromatography for Anions (IC-Anions)}

For IC Anions, samples were diluted with a carbonate/bicarbonate diluent as necessary to bring analytes to within instrument calibration. A 3-point calibration curve is run daily on the instrument with concentrations of 10,25 and $50 \mu \mathrm{g} / \mathrm{mL}$.

\section{Atomic Absorption Spectroscopy (AA)}

Arsenic, selenium, and mercury are analyzed by AA. The mercury was determined using the cold vapor technique. Samples were diluted as necessary to bring analytes within the instrument calibration range. An instrument calibration is performed daily with a blank and two or three point standard. The standard is run for each element at the beginning of the day, after each five sample runs and at the end of the day.

\section{Inductively Coupled Plasma - Mass Spectroscopy (ICP-MS)}

Samples were run concurrently with a laboratory control standard (LCS) containing V, Co, As, Sr, Mo, Ru, Ag, Cd, Sb, Cs, Ba, La, Eu, Ho, Yb, Tl, Pb, Th, and U. This LCS provided a 
SRNL-STI-2012-00034, Rev. 1

August 3, 2012

Page 45 of 50

mass response covering most of the mass range of interest. The following describes the calculation of the analytes of interest from the mass values:

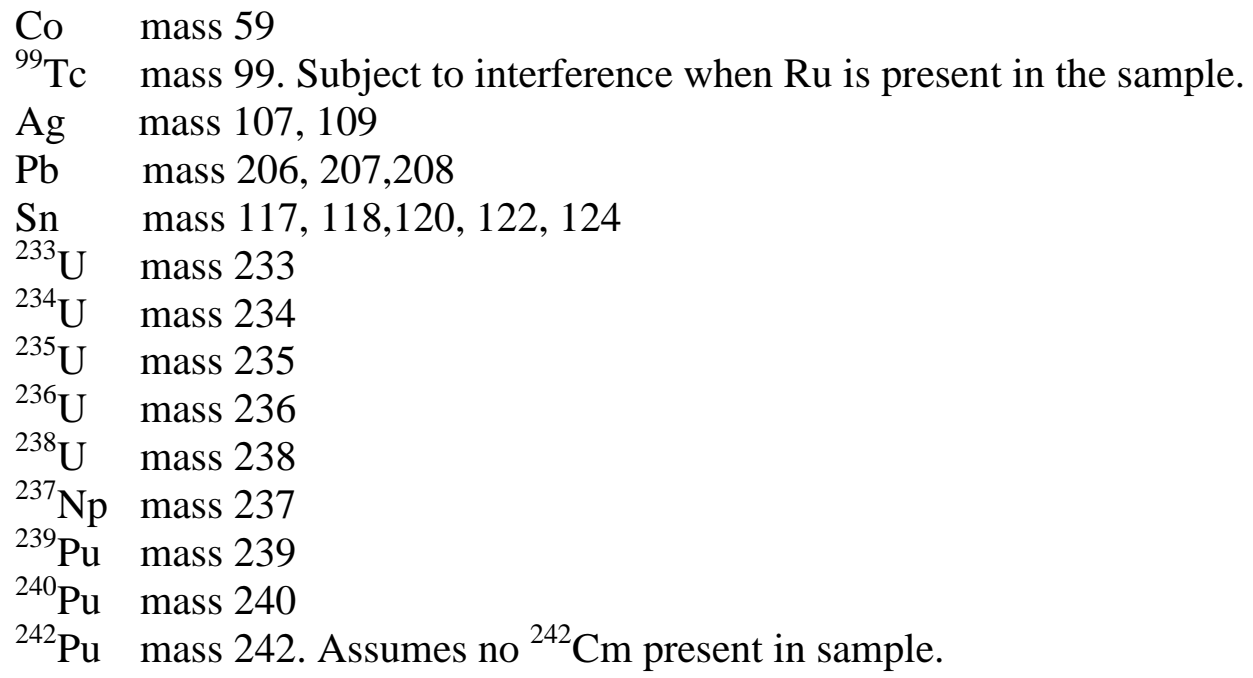

\section{Gross Alpha/Gross Beta}

The solid material was too concentrated to be analyzed directly. Aliquots of peroxide fusion dissolution were added to liquid scintillation cocktail and analyzed for gross alpha and gross beta activity using liquid scintillation analysis. Alpha/beta spillover was determined for each aliquot analyzed, and subsequently used for accurately determining alpha and beta activity, via the addition of a known amount of plutonium to an identical aliquot of each sample.

\section{Other Specialty Separations and Preparations}

\section{Ni-59/63}

Aliquots of dissolution from the aqua regia digestion were aliquoted and spiked with an elemental nickel carrier. The nickel species were extracted from the matrix using dimethylglyoxime (DMG) based extractant. Ni-59 concentrations were measured using low energy photon/x-ray, thin-windowed, semi-planar high purity germanium spectrometers. Ni63 concentrations were measured by liquid scintillation analysis. Elemental nickel carrier yields were measured by ICP-ES, and were used to correct the radioactive nickel species' analyses for any nickel losses from the radiochemical separations.

\section{Cs-137/Cs-134}

Aliquots of peroxide fusion dissolution and AQR were analyzed by coaxial high purity germanium gamma-ray spectrophotometers to measure Cs-137 and Cs-134.

\section{Sr-90}

Aliquots of peroxide fusion and AQR dissolutions were spiked with an elemental strontium carrier. The strontium species were extracted from the matrix using a crown-ether-based solid phase extractant. Sr-90 concentrations were measured by liquid scintillation analysis. Elemental strontium carrier yields were measured by neutron activation analysis, and were 
SRNL-STI-2012-00034, Rev. 1

August 3, 2012

Page 46 of 50

used to correct the Sr-90 analyses for any strontium losses from the radiochemical separations.

\section{Pm-147/Sm-151}

Aliquots of peroxide fusion and AQR dissolution were spiked with an elemental samarium carrier. The promethium and samarium species were extracted from the matrix using a combination of Octylphenyl-N,N-di-isobutyl carbamoylphosphine oxide/tri-n-butyl phosphate (one CMPO/TBP) and di(2-ethylhexyl) orthophosphoric acid (one HDEHP based). Sm-151 and Pm-147 concentrations were measured by liquid scintillation analysis. The matrix was high in Sm-151, but the short-lived Pm-147 component of the material had decayed below noise levels of the analysis. Elemental samarium carrier yields were measured by neutron activation analysis, and were used to correct the analyses for any samarium losses from the radiochemical separations. The separation was designed to extract both Sm and Pm together; a Pm spike was run with the samples to confirm this.

Na-22, Al-26, Co-60, Nb-94, Rh-106, Ru-106, Sb-125, Sb-126, Sn-126, Sb-126m, Te125m, Ce-144, Pr-144, Eu-152, Eu-154, Eu-155, Am-241, Ra-228, Ac-227

Aliquots of peroxide fusion were subjected to a Cs-removal process utilizing Bio Rad AMP1 resin. The Cs-removed digestates were analyzed by coaxial high purity germanium spectrophotometers to measure the gamma-emitting radionuclides listed above.

\section{Pu-238, 239/240, 241}

Aliquots of peroxide fusion and AQR dissolutions were spiked with $\mathrm{Pu}-236$ tracer. The plutonium was extracted from the matrix using thenoyltrifluoroacetone (TTA) following a series of oxidation-state adjustments. The TTA extracts were mounted on stainless steel counting plates and counted for Pu-238 and Pu-239/240 using PIPs detectors. Each separation was traced based on the Pu-236 recovery. Aliquots of sample were also subjected to Cs-removal with Bio-Rad Ammonium Molybdophosphate (AMP) resin and extracted using TEVA columns (TEVA Brand name for one of Eichrom's resins). The Pu-containing extracts were measured by liquid scintillation analysis to determine $\mathrm{Pu}-241$ concentration.

Am-241, 242m, 243, Cm-242, 243, 244, 245, 247, 248, Cf-249, 251, 252

Samples of composite Tank 5F materials were digested using a sodium peroxide fusion. Additionally, a matrix blank and matrix blank spiked with Am-241 and Cm-244 were prepared using Tank 8 simulated sludge. The americium, curium and californium species were extracted from aliquots of peroxide fusion using a CMPO/TBP based solid phase extractant and purified further with an HDEHP based solid phase extractant. Am-241, 243, Cm-243, 245, 247, Cf-249 and 251 concentrations were measured using low energy photon/x-ray, thin-windowed, semi-planar high purity germanium spectrometers. Am-242m, Cm-242, 244, 248, Cf-252 concentrations were measured using passivated, implanted, planar silicon (PIPS) alpha spectrometers. Some of the Am, Cm and Cf isotopes were also measured using ICP-MS. Am-241 quantities had been measured from the cesium removed gamma analyses, all Am, Cm, and Cf results were traced with the Am-241 present in the sample matrix. 
SRNL-STI-2012-00034, Rev. 1

August 3, 2012

Page 47 of 50

U-232

Aliquots of peroxide fusion were spiked with a U-233 radioactive tracer, additional aliquots were run through the method with no tracer added. Uranium was extracted from the matrix using two stages of a diamyl, amylphosphonate (DAAP)-based solid phase extraction and purified further via co-precipitation with cerium. U-232, U-233, and U-238 activities were measured using passivated, implanted, planar silicon (PIPS) alpha spectrometers. The Tank 5 samples were so high in U-234, the U-233 tracers (which have the same alpha energy as U234) were swamped out. U-232/U-238 activity ratios were generated and were multiplied to U-238 activities measured with the ICP-MS to determine U-232 activities in the samples.

\section{Cs-135 Separation for MS}

Aliquots of dissolved material (alkali fusion digestion) were purified using a solvent-solvent caustic side solvent extraction-based (CSSX) extraction system. The purified Cs-containing aliquots were analyzed using ICP-MS to measure Cs-135/Cs-133 mass ratios. The Cs-133 and Ba-corrected Cs-135 ratios from the aliquots of separated material were used along with the associated Cs-133 ICP-MS result from the analysis of non-separated material to obtain a value for Cs-135. The Cs-135 result was then converted from ug/g to $\mathrm{uCi} / \mathrm{g}$ using the specific activity of Cs-135.

\section{Np-237}

Aliquots of peroxide fusion dissolution were spiked with $\mathrm{Np}-239$ and then purified with a quaternary amine based solid phase extraction. The purified aliquots were analyzed by low energy photon/x-ray, thin-windowed, semi-planar high purity germanium spectrometers to yield the Np-239 recoveries and by the ICP-MS to measure Np-237. The Np-237 values were corrected with the decay-corrected Np-239 recoveries.

\section{Tritium}

Aliquots of dissolution from the aqua regia digestion were subjected to tritium separations via steam distillation, and aliquots of the tritium-containing distillate were analyzed by liquid scintillation analysis.

\section{Se-79}

Samples of composite Tank 5F materials were weighed out, spiked with an elemental selenium carrier and digested in concentrated acid. The selenium species were extracted from the matrix using a combination of resin decontamination, selenium metal precipitation, and TBP-based liquid-liquid extractions. The purified selenium products were analyzed by liquid scintillation to measure Se-79, and by neutron activation analysis to measure elemental selenium carrier yields. The selenium carrier yields were used to correct the Se-79 analyses for any selenium losses from the radiochemical separations.

\section{Tc-99}

Tank 5F composite samples were digested in a combination of concentrated nitric and hydrochloric acids. Several matrix blanks were prepared using Tank 8 simulated sludge spiked with a Tc-99 standard. The dissolutions were subjected to a number of resin 
treatments to reduce dose prior to removal from the shielded cells. The treated samples were then spiked with Tc-99m and the technetium species were extracted from the matrix using an Aliquat-336 based solid phase extractant. Tc-99 concentrations were measured by liquid scintillation analysis. Tc-99m yields were measured with a NaI-well gamma spectrometer, and were used to correct the Tc-99 analyses for any technetium losses from the radiochemical separations. The average recovery of the Tc-99 spiked matrix blank was applied to the entire set of samples to correct for any losses from the decontamination steps used in the shielded cells.

\section{Ra-226}

Tank 5F composite samples were digested using a sodium peroxide fusion. Each replicate was prepared in duplicate with the duplicate containing a Ra-224 tracer. Additionally, a matrix blank and matrix spiked blank were prepared using Tank 8 simulated sludge. The Ra226 was extracted from the matrix using a combination of resin decontamination and ion exchange. The purified Ra-226 was sealed in polypropylene tubes and stored for several daughter Rn-222 half-lives. The Ra-226 progeny daughter isotope $\mathrm{Pb}-214$ was then analyzed for using a high purity germanium well gamma ray spectrophotometer and results were corrected for the tracer Ra-224 recoveries.

\section{Pa-231}

Tank 5F composite samples were digested using a sodium peroxide fusion. Each replicate was prepared in duplicate with the duplicate containing a Pa-233 tracer. Additionally, a matrix blank and matrix spiked blank were prepared using Tank 8 simulated sludge. The dissolutions were decontaminated with AMP and quaternary amine based resins. Protactinium species were then extracted from the matrix using a CMPO/TBP based extractant. Pa-233 tracer concentrations were measured using high purity germanium spectrometers to determine separation yields. Pa-231 was measured using the ICP-MS. The $\mathrm{Pa}-233$ tracer yields were decay corrected and then used to correct the Pa-231 analyses for any losses from the radiochemical separations.

\section{I-129}

Tank 5F composite samples were dissolved in concentrated acid with an added KI carrier. A matrix blank and matrix blank containing an I-129 spike were also prepared using Tank 8 simulated sludge. Actinide and AMP resins were then added to the mixture to facilitate removal of interfering isotopes. Sodium sulfite is added to the material to reduce the iodine. Silver nitrate is added to the solution to precipitate the iodine as AgI, which is separated via filtration. The filtrate is analyzed for I-129 content using low energy photon/x-ray, thinwindowed, semi-planar, high purity germanium spectrometers. Elemental iodine yields were measured by neutron activation analysis, and were used to correct the I-129 analyses for any iodine losses from the radiochemical separation.

\section{C-14}

The solid material was used for the $\mathrm{C}-14$ separation and analysis. The material was added to a mixture of sodium hydroxide, and sodium carbonate/sodium hydroxide. A series of oxidation and reduction steps designed to liberate C-14 containing carbon dioxide were 
SRNL-STI-2012-00034, Rev. 1

August 3, 2012

Page 49 of 50

carried out, which selectively trapped the C-14 in a basic solution. Finally, C-14 containing carbon dioxide was captured in Carbosorb $\mathrm{E}$ and measured by liquid scintillation analysis.

\section{Th-229/230, Ac-227}

Tank 5F composite samples were digested using a sodium peroxide fusion. Each replicate was prepared in duplicate with the duplicate containing a Th-229 tracer. Additionally, a matrix blank and matrix spiked blank were prepared using Tank 8 simulated sludge. The matrix spiked blank contained both a Th-228 and Th-229 spike. Thorium was extracted from the matrix using two stages of a quaternary amine based solid phase extraction and purified further via co-precipitation with cerium. Th-227, Th-229 and Th-230 concentrations were measured using passivated, implanted, planar silicon (PIPS) alpha spectrometers. The Th-229 tracer yields were used to correct the various analytes analyses for any thorium losses from the radiochemical separations. Ac-227 activities were calculated from the Th-227 results

\section{Cl-36}

Tank 5F composite samples were dissolved in triplicate using a mixture of concentrated hydrochloric and nitric acids, along with a Tank 8 simulated sludge blank and a Cl-36 spiked simulated sludge blank. The samples were contacted with resins to reduce activity before removal from the shielded cells. The samples were then contacted with resins again to further decontaminate the samples, steam distilled, and finally the Cl-36 was precipitated as AgCl. The AgCl precipitate was counted for total beta using a gas flow proportional counter. The precipitate was then analyzed by NAA to determine $\mathrm{Cl}$ chemical yields to trace the separation.

\section{K-40}

Tank 5F composite samples were digested using a sodium peroxide fusion. The samples were subjected to a series of decontamination steps to remove Cs-137, Sr-90 as well as a number of trivalent, tetravalent and hexavalent radionuclides. The decontaminated solutions were then analyzed with high purity germanium detectors.

\section{Pt-193}

Aliquots of Tank 5F peroxide fusion dissolutions were spiked with stable Pt and then purified with a quaternary amine based solid phase extraction. The purified aliquots were analyzed by low energy photon/x-ray, thin-windowed, semi-planar high purity germanium spectrometers to measure Pt-193m and by the ICP-ES to measure stable Pt recoveries. The Pt-193m values were corrected with the stable Pt recoveries.

\section{Nb-94}

Aliquots of peroxide fusion dissolution were spiked with Nb-95 and then purified with a anion exchange. The purified aliquots were analyzed by high purity germanium spectrometers to measure Nb-94 and to measure Nb-95 tracer recoveries. The Nb-94 values were corrected with the stable Nb-95 recoveries. 


\section{Pd-107}

Page 50 of 50

Tank 5F composite samples were dissolved in triplicate using hot aqua regia along with a Tank 8 simulated sludge blank and a Pd spiked simulated sludge blank. The samples were contacted with resins to reduce activity before removal from the shielded cells. Pd was extracted from the samples using a DMG based extractant. Pd-107 levels were measured using the ICP-MS, and the results were yielded from sample stable Pd recoveries as measured by the ICP-MS

\section{Zr-93}

Zr was extracted from aliquots of peroxide fusion dissolution. Zr-93 levels were measured using the ICP-MS, and the results were yielded from sample stable $\mathrm{Zr}$ recoveries as measured by the ICP-MS.

\section{Weight Fraction Solids Measurement}

The weight percent total solids in each Tank 5F sample were measured in the Shielded Cells using a conventional drying oven at $110{ }^{\circ} \mathrm{C}$. An aliquot of each composite sample was placed in a container. The container was placed in the oven. The weights of the dried sample were checked periodically over 72 hours until two consecutive weights yielded comparable results. The weight fraction solid was calculated by dividing the dry weight of the sample by the initial weight of the sample. A 5\% sodium chloride salt solution prepared by dissolving 5 grams of dried sodium chloride in distilled water was used as the reference matrix for weight percent determinations as described above.

\section{Density Measurement}

The bulk densities of the "as-received" granular Tank 5F solids were measured using a calibrated syringe tube assembly with graduation markings. With the syringe plunger removed, the syringe was loaded with Tank 5F solids with the help of a spatula to a level of about 2-mL. The plunger was then inserted into the syringe until the tip of the plunger touched the sample matrix, taking care not to excessively compress the sample. The plunger was then slightly pulled back and tapped to ensure the granular solid was uniformly distributed around the circumference of the tube. The volume of samples in the tube was read and the weight of the whole syringe assembly including the plunger was determined. A subtraction of the weight of the assembly without the granular samples provided the weight of the granular sample inside the syringe tube. Using the same syringe unit, the plunger was carefully removed and more granular sample was added to the syringe and the new volume and weight of the granular samples determined again. Using different syringe assemblies, this process was repeated three times for each Tank 5F sample. 